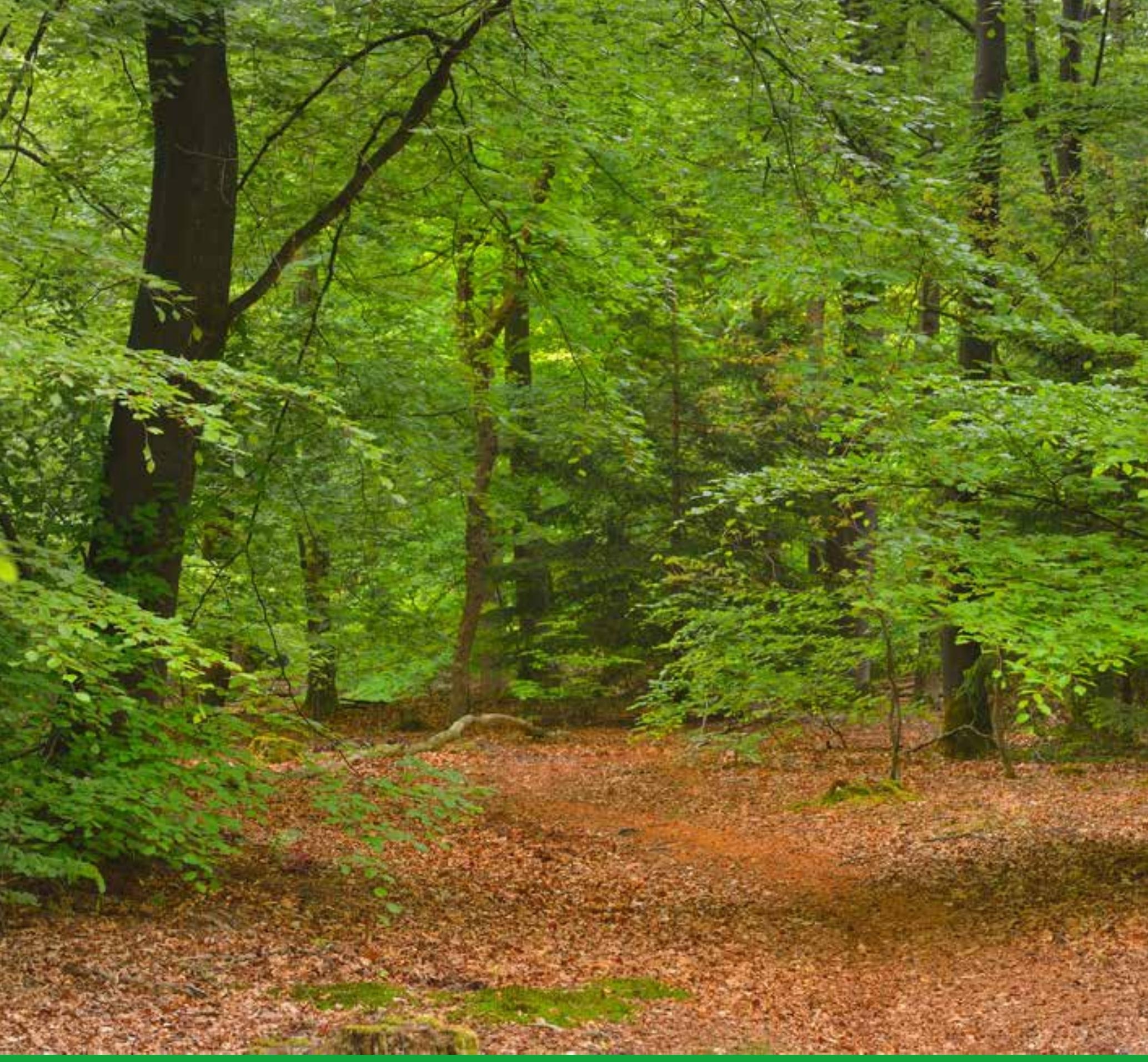

\title{
Bedrijfsuitkomsten in de Nederlandse particuliere bosbouw over 2019
}

H.J. Silvis en M.J. Voskuilen 



\section{Bedrijfsuitkomsten in de Nederlandse particuliere bosbouw over 2019}

H.J. Silvis en M.J. Voskuilen 
Silvis, H.J. en M.J. Voskuilen, 2021. Bedrijfsuitkomsten in de Nederlandse particuliere bosbouw over 2019. Wageningen, Wageningen Economic Research, Rapport 2021-044. 48 blz.; 10 fig.; 16 tab.; 0 ref.

Dit rapport biedt een overzicht van de bedrijfsresultaten van particuliere bosbedrijven in 2019. Hierbij gaat het om particuliere boseigenaren met meer dan 50 ha bos, met uitzondering van de particuliere natuurbeschermingsorganisaties. De Nederlandse particuliere bosbedrijven boekten in 2019 een bedrijfsresultaat van gemiddeld min 10 euro per ha bos, tegen plus 22 euro per ha bos in 2018 . Terwijl de opbrengsten daalden (-9\%) stegen de kosten (2\%). De opbrengsten-kostenverhouding kwam in 2019 uit op $97 \%$ tegen $108 \%$ in 2018.

Het onderzoeksproject is uitgevoerd binnen de Wettelijke Onderzoekstaak voor het Ministerie van Landbouw, Natuur en Voedselkwaliteit. De uitvoering wordt gecoördineerd door het Centrum voor Economische Informatievoorziening (CEI). Het CEI bewaakt het onafhankelijke karakter van het onderzoek en de kwaliteitsborging.

Trefwoorden: bosbouw, bedrijfsresultaten, opbrengsten, kosten, bedrijfsgrootte, regio

Dit rapport is gratis te downloaden op https://doi.org/10.18174/546246 of op www. wur. nl/economicresearch (onder Wageningen Economic Research publicaties).

(C) 2021 Wageningen Economic Research

Postbus 29703, 2502 LS Den Haag, T 07033583 30, E communications.ssg@wur.nl, www.wur. nl/economic-research. Wageningen Economic Research is onderdeel van Wageningen University \& Research.

\section{(cc) BY-NC}

Dit werk valt onder een Creative Commons Naamsvermelding-Niet Commercieel 4.0 Internationaallicentie.

(c) Wageningen Economic Research, onderdeel van Stichting Wageningen Research, 2021

De gebruiker mag het werk kopiëren, verspreiden en doorgeven en afgeleide werken maken. Materiaal van derden waarvan in het werk gebruik is gemaakt en waarop intellectuele eigendomsrechten berusten, mogen niet zonder voorafgaande toestemming van derden gebruikt worden. De gebruiker dient bij het werk de door de maker of de licentiegever aangegeven naam te vermelden, maar niet zodanig dat de indruk gewekt wordt dat zij daarmee instemmen met het werk van de gebruiker of het gebruik van het werk. De gebruiker mag het werk niet voor commerciële doeleinden gebruiken.

Wageningen Economic Research aanvaardt geen aansprakelijkheid voor eventuele schade voortvloeiend uit het gebruik van de resultaten van dit onderzoek of de toepassing van de adviezen.

Wageningen Economic Research is ISO 9001:2015 gecertificeerd.

Wageningen Economic Research Rapport 2021-044 | Projectcode 2282200608

Foto omslag: Shutterstock 


\section{Inhoud}

Woord vooraf $\quad 5$

Samenvatting $\quad 6$

$\begin{array}{lll}\text { S.1 Belangrijkste uitkomsten } & 6\end{array}$

$\begin{array}{lll}\text { S.2 Overige uitkomsten } & 7\end{array}$

$\begin{array}{lll}\mathrm{S} .3 \text { Methode } & 7\end{array}$

$\begin{array}{llr}1 & \text { Resultaten van bosbedrijven } & 8\end{array}$

$\begin{array}{lll}1.1 & \text { Bedrijfsresultaten } & 8\end{array}$

$\begin{array}{lll}1.2 & \text { Opbrengsten } & 8\end{array}$

$\begin{array}{llr}1.3 & \text { Houtprijs en oogstvolume } & 9\end{array}$

$\begin{array}{lll}1.4 & \text { Kostensoorten } & 10\end{array}$

$\begin{array}{lll}1.5 & \text { Kostenplaatsen } & 11\end{array}$

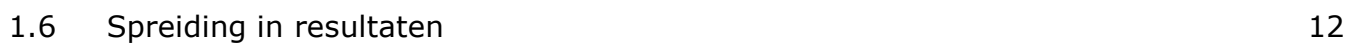

$2 \quad$ Resultaten naar bedrijfsgrootte 13

$\begin{array}{lll}2.1 & \text { Bedrijfsresultaten } & 13\end{array}$

2.2 Opbrengsten 14

2.3 Kosten 15

$\begin{array}{llr}3 & \text { Resultaten nar regio } & 17\end{array}$

$\begin{array}{lll}3.1 & \text { Bedrijfsresultaten } & 17\end{array}$

$\begin{array}{lll}3.2 & \text { Opbrengsten } & 17\end{array}$

$\begin{array}{lll}3.3 & \text { Kosten } & 18\end{array}$

$4 \quad$ Resultaten op lange termijn $\quad 20$

$\begin{array}{lll}4.1 & \text { Bedrijfsresultaten } & 20\end{array}$

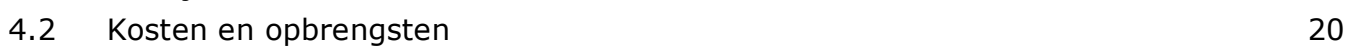

4.3 Houtprijzen en oogstvolume $\quad 22$

$\begin{array}{lll}\text { Bijlage } 1 \text { Verantwoording } & 24\end{array}$

$\begin{array}{lll}\text { Bijlage } 2 & \text { Tabellen } & 31\end{array}$ 



\section{Woord vooraf}

De monitoring van de bedrijfseconomische aspecten van het bosbeheer gebeurt onder meer ten behoeve van het beleid van de overheid. In de Bossenstrategie geven Rijk en provincies een streefbeeld voor het bos in Nederland tot 2030. Begin 2020 formuleerden ze gezamenlijk ambities en doelen voor de Bossenstrategie. Deze werkten ze verder uit en formuleerden daarbij acties om de doelen en de ambities te realiseren. De gewenste koers is het goed doorgeven van bos met zijn verschillende functies aan toekomstige generaties: Bos voor de toekomst (IPO en LNV, 2020). ${ }^{1}$ Een van die functies is de economische functie van bossen.

Dit rapport geeft een overzicht van de bedrijfsresultaten, opbrengsten en kosten van particuliere bosbedrijven met meer dan 50 ha bos. De resultaten in 2019 worden afgezet tegen die in de voorafgaande jaren. In de bijlage zijn ook de resultaten van bedrijven met minder dan 50 ha bos opgenomen.

In aanvulling op de gemiddelde resultaten van de onderscheiden bedrijven, gaat het rapport in op de resultaten naar grootte van het bosbezit (50-100 ha, 100-250 ha en 250 ha en meer) en naar regio (Noordoost, Centrum en Zuid). Ten slotte worden de reële resultaten op lange termijn (1975-2019) geschetst. De verantwoording van doel en opzet van het onderzoek en de toelichting op de gehanteerde begrippen en rekenregels zijn opgenomen in de bijlagen.

Veel dank is verschuldigd aan de eigenaren en beheerders van particuliere bosbezittingen die, door het ter beschikking stellen van bedrijfsgegevens, deze publicatie mogelijk hebben gemaakt. De dataverzameling is verzorgd door Jeroen Bremer, René van den Broek, Henk Nuijen, Gunther Tap en Roel van der Velde. Namens het ministerie van LNV is Zev Starmans opgetreden als contactpersoon.

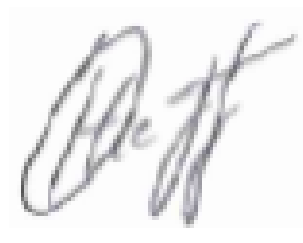

Ir. O. Hietbrink, Olaf Business Unit Manager Wageningen Economic Research Wageningen University \& Research

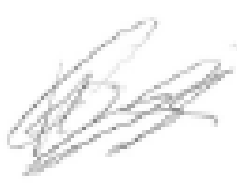

Dr. H.C.J. Vrolijk Hoofd WOT Economische Informatievoorziening

\footnotetext{
1 Bos voor de toekomst; Uitwerking ambities en doelen landelijke Bossenstrategie en beleidsagenda 2030 . Uitgave van het ministerie van Landbouw, Natuur en Voedselkwaliteit en de gezamenlijke provincies. November 2020 | Publicatie-nr. 1120-001.
} 


\section{Samenvatting}

\section{S.1 Belangrijkste uitkomsten}

De Nederlandse particuliere bosbedrijven (groter dan 50 ha) sloten 2019 af met een negatief bedrijfsresultaat (opbrengsten minus kosten) van gemiddeld min 10 euro per ha bos (tabel S.1). Dat is 32 euro onder het resultaat van 2018 door lagere opbrengsten $(-9 \%)$ en hogere kosten $(+2 \%)$. De opbrengsten-kostenverhouding kwam in 2019 uit op 97\%, tegen 108\% in 2018.

Tabel S.1 Resultaten (euro per ha bos), 2014-2018

\begin{tabular}{|c|c|c|c|c|c|}
\hline & 2015 & 2016 & 2017 & 2018 & 2019 \\
\hline Opbrengsten & 271 & 272 & 271 & 289 & 263 \\
\hline Kosten & 233 & 245 & 274 & 268 & 273 \\
\hline Opbrengsten/kosten (\%) & 116 & 111 & 99 & 108 & 97 \\
\hline Inkomen uit het bosbedrijf & 52 & 41 & 11 & 35 & 3 \\
\hline
\end{tabular}

Bron: Bedrijveninformatienet, Wageningen Economic Research.

Het gemiddelde inkomen uit het bosbedrijf - het bedrijfsresultaat plus de berekende arbeidsvergoeding (in hoofdzaak van de eigenaar) - kwam in 2019 uit op 3 euro per ha per bos, tegen 35 euro per ha in 2019. De inbreng van de eigen arbeid (per ha) van de boseigenaar is vrij klein en daarmee ook de bijdrage aan het inkomen. De hiervoor in rekening gebrachte bedragen lagen in de afgelopen vijf jaar tussen de $5 \%$ à $6 \%$ van de totale kosten.

Het gemiddeld reëel bedrijfsresultaat van particuliere bosbedrijven (groter dan 50 ha) laat over de lange termijn (1975-2019) een positieve trend zien met pieken en dalen (figuur S.1). In de periode 1975-1990 was het gemiddelde resultaat 32 euro per ha negatief, terwijl tussen 2006 en 2019 een gemiddeld positief resultaat werd geboekt van 34 euro per ha bos. In de laatste periode was 2019 het jaar met het slechtste resultaat.

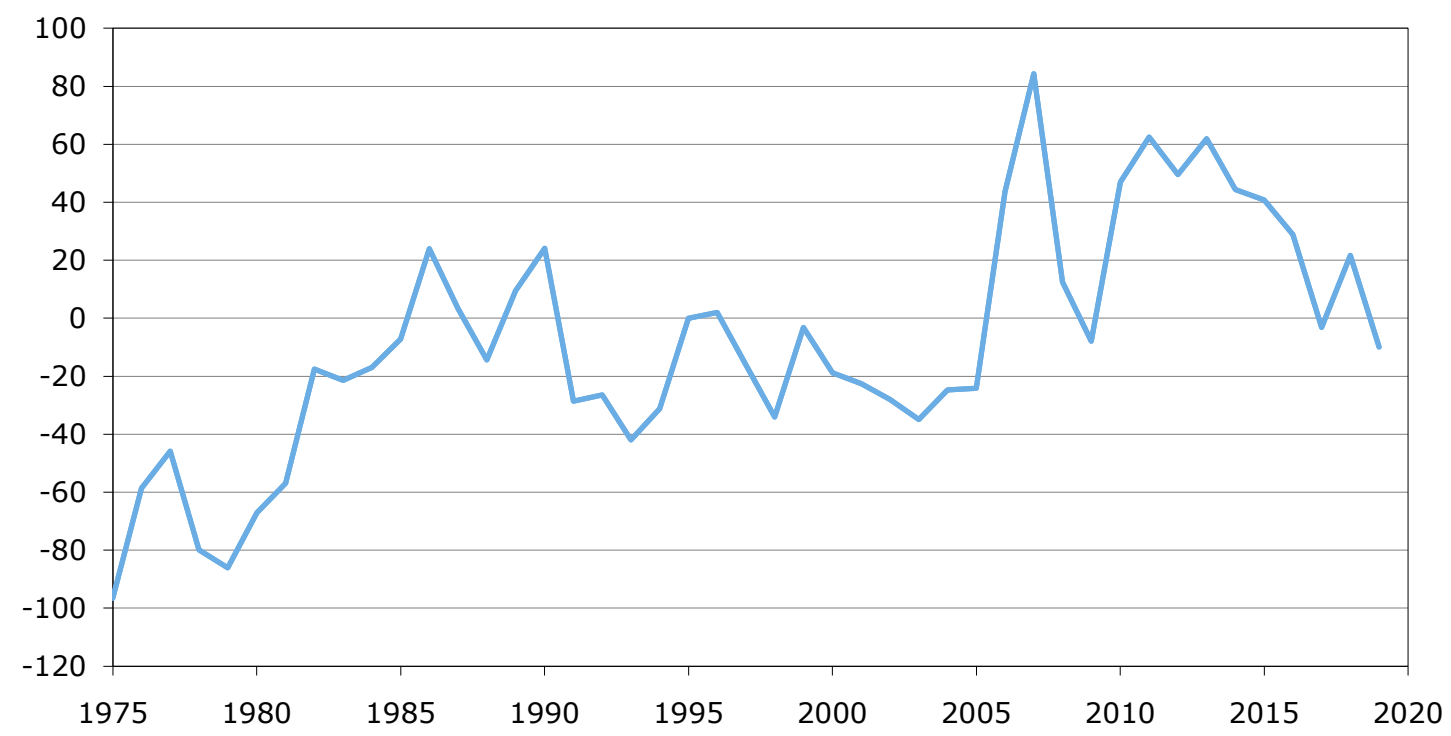

Figuur S.1 Gemiddeld reëel bedrijfsresultaat per ha bos (in euro's van 2019), 1975-2019 Bron: Bedrijveninformatienet, Wageningen Economic Research. 


\section{S.2 Overige uitkomsten}

De resultaten van de bosbedrijven vertonen onderling grote verschillen. In 2019 had 36\% van de bedrijven een bedrijfsresultaat van minder dan -100 euro per ha, en $25 \%$ een resultaat van meer dan 100 euro per ha. Gemiddeld heeft 48\% van de bedrijven in de periode 2017-2019 een positief resultaat behaald. De bedrijven die uit de rode cijfers bleven, beheerden $50 \%$ van het bosareaal.

Er zijn verschillen in resultaten tussen kleine (van 50 tot $100 \mathrm{ha}$ ), middelgrote (100 tot 250 ha) en grote ( 250 ha bos of meer) bedrijven. De kleine en middelgrote bedrijven boekten in 2019 een negatief bedrijfsresultaat van respectievelijk 54 en 26 euro per ha bos, terwijl de grote bedrijven het jaar afsloten met een plus van 15 euro per ha.

In de regio's Noordoost en Centrum daalde het bedrijfsresultaat in 2019 tot respectievelijk min 14 euro en min 40 euro per ha. In Noordoost is de verslechtering van het resultaat ten opzichte van het gemiddelde in de jaren 2015-2018 vooral het gevolg van hogere kosten. In Centrum zijn het vooral de lagere opbrengsten die zorgden voor het lagere resultaat. In de regio Zuid verbeterde het bedrijfsresultaat in 2019 tot 38 euro per ha door hogere opbrengsten (en iets hogere kosten) in vergelijking met de gemiddelde uitkomsten in de periode 2015-2018.

\section{S.3 Methode}

De jaarlijkse publicatie van Wageningen Economic Research over de bedrijfsuitkomsten in de Nederlandse particuliere bosbouw verschijnt op verzoek van het ministerie van Landbouw, Natuur en Voedselkwaliteit. De publicatie verschaft informatie over de bedrijfsresultaten (in euro per ha bos) van particuliere bedrijven. Hierbij gaat het om particuliere boseigenaren, met uitzondering van de natuurbeschermingsorganisaties. De resultaten zijn gebaseerd op het Bedrijveninformatienet van Wageningen Economic Research (zie bijlage 1). De administraties hebben alleen betrekking op de resultaten van het bosbedrijf. Met de vergelijking van de jaarlijkse uitkomsten moet voorzichtig worden omgegaan, omdat de bedrijfsvoering in het bos op de lange termijn is gericht en de werkzaamheden (beheer, verjonging, onderhoud, vellingen) niet steeds gelijkmatig over de jaren gespreid zijn. 


\section{Resultaten van bosbedrijven}

\subsection{Bedrijfsresultaten}

Gemiddeld bedrijfsresultaat negatief

De Nederlandse particuliere boseigenaren met meer dan 50 ha bos sloten 2019 af met een bedrijfsresultaat (saldo van opbrengsten en kosten, inclusief berekende arbeidskosten) van gemiddeld min 10 euro per ha bos (tabel 1.1). Dat is 32 euro onder het resultaat van 2018 door lagere opbrengsten $(-9 \%)$ en iets $(+2 \%)$ hogere kosten. De opbrengsten-kostenverhouding kwam in 2019 uit op $97 \%$, tegen $108 \%$ in 2018 .

Tabel 1.1 Resultaten (euro per ha bos), 2015-2019

\begin{tabular}{lrrrrr} 
& 2015 & 2016 & 2017 & 2018 & 2019 \\
Opbrengsten & 271 & 272 & 271 & 269 & 268 \\
\hline Kosten & 233 & 245 & -3 & 273 \\
\hline Bedrijfsresultaat & 38 & 27 & -10 \\
\hline Opbrengsten/kosten (\%) & 116 & 111 & 99 & 108 \\
\hline Inkomen uit het bosbedrijf & 52 & 41 & 11 & 35 & 37 \\
\hline
\end{tabular}

Bron: Bedrijveninformatienet, Wageningen Economic Research.

\section{Beperkte inbreng eigen arbeid}

Het inkomen uit het bosbedrijf is in 2019 uitgekomen op 3 euro per ha per bos, tegen 35 euro per ha in 2019 (tabel 1.1). Het inkomen uit het bosbedrijf, de beloning van de eigenaar voor risico, management en arbeid, wordt berekend door het bedrijfsresultaat te vermeerderen met de berekende arbeidskosten van de eigenaar (zie bijlage 1.6) en de overige berekende lonen (die laatste zijn te verwaarlozen). De inbreng van de eigen arbeid (per ha) van de boseigenaar is vrij klein en daarmee ook de bijdrage aan het inkomen. De hiervoor in rekening gebrachte bedragen lagen in de afgelopen vijf jaar tussen de $5 \%$ à $6 \%$ van de totale kosten.

\subsection{Opbrengsten}

Afname houtopbrengsten

De gemiddelde opbrengsten van de particuliere bosbedrijven daalden in 2019 met 9\%, van 289 euro in 2018 tot 263 euro per ha in 2019 (tabel 1.2). Dat is ook onder het meerjarig gemiddelde in de periode 2015-2018 (276 euro per ha per jaar).

Tabel 1.2 Opbrengsten (euro per ha bos), 2015-2019

\begin{tabular}{|c|c|c|c|c|c|}
\hline & 2015 & 2016 & 2017 & 2018 & 2019 \\
\hline Hout & 129 & 136 & 126 & 142 & 122 \\
\hline w.o. op stam & 114 & 116 & 111 & 130 & 100 \\
\hline Beheersubsidie & 77 & 77 & 77 & 85 & 83 \\
\hline Overige subsidies & 10 & 16 & 28 & 14 & 13 \\
\hline Recreatie & 15 & 15 & 13 & 17 & 17 \\
\hline Overig & 22 & 11 & 11 & 15 & 13 \\
\hline Totaal & 271 & 272 & 271 & 289 & 263 \\
\hline
\end{tabular}

Bron: Bedrijveninformatienet, Wageningen Economic Research. 
De afname van de opbrengsten in 2019 is in hoofdzaak het gevolg van de lagere houtopbrengsten. Deze daalden met 14\% (ten opzichte van 2018) tot 122 euro per ha bos door een vrij sterke daling van de houtprijs (zie paragraaf 1.3). In 2019 bedroegen de houtopbrengsten $46 \%$ van de totale opbrengsten (figuur 1.1), iets (2 procentpunt) onder het niveau in de periode 2015-2018.

Subsidies gelijk

De totale subsidies kwamen in 2019 uit op 96 euro per ha, evenveel als het gemiddelde in de vier voorgaande jaren (2015-2018). Daarmee zijn ze goed voor 36\% van de totale opbrengsten (figuur 1.1), wat vrijwel gelijk is aan de gemiddelde bijdrage van de subsidies in de periode 20152018.

Het grootste deel (ruim 80\% tussen 2015-2019) van de subsidies bestaat uit een structurele bijdrage aan de beheerkosten van het bos via Subsidiestelsel Natuur en Landschap (SNL), waaronder een openstellingsbijdrage. De bijdrage aan de directe werkzaamheden natuur- en landschapsbeheer wordt bepaald op basis van de 'standaardkostprijs' die per type natuurtype wordt berekend. De SNL-tarieven bedragen een percentage (doorgaans 75\%) van deze kostprijs. In 2018 is de standaardkostprijs voor bos met productiefunctie aangepast. In 2019 bedraagt het tarief voor 'droog bos met productiefunctie' 26 euro per ha (24 euro in 2018) en voor 'vochtig bos met productiefunctie' 45 euro per ha (44 euro in 2018). In de jaren 2014-2017 lagen ze gemiddeld op ongeveer 5 euro en 15 euro per ha. Voor actuele informatie over het SNL wordt verwezen naar de website van BIJ12, een uitvoeringsorganisatie voor de twaalf provincies (www.bij12.nl).

De overige subsidies - 13 euro per ha in 2019 - zijn afkomstig van verschillende verstrekkers en hebben geen structureel karakter.

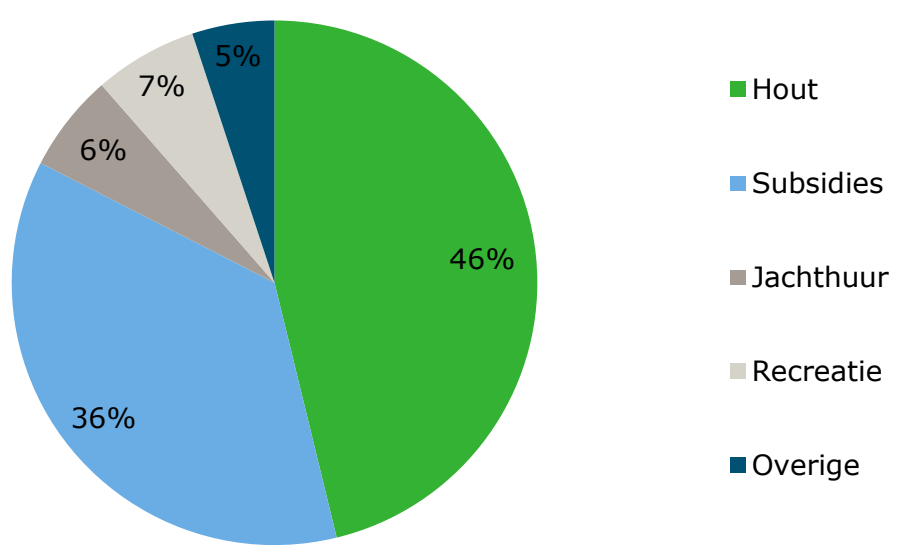

Figuur 1.1 Verdeling (\%) van de opbrengsten, 2019

Bron: Bedrijveninformatienet, Wageningen Economic Research.

\section{Overige opbrengsten constant}

De overige opbrengstenposten (jachthuur, recreatie en overig) brachten in 2019 gemiddeld 46 euro per ha op, ofwel $17 \%$ van de totale opbrengsten. De omvang van deze overige opbrengstenposten is door de jaren vrij stabiel.

\subsection{Houtprijs en oogstvolume}

Houtprijs omlaag

In 2019 daalde de gemiddelde houtprijs met 20\% (ten opzichte van 2018) tot 33 euro per $\mathrm{m}^{3}$ (tabel 1.3). In 2016 bereikte de gemiddelde houtprijs een piek met 42 euro per $\mathrm{m}^{3}$. 
Tabel 1.3 Opbrengstprijzen (euro per $\mathrm{m}^{3}$ ) van verkocht hout naar verkoopwijze, 2015-2019

\begin{tabular}{llllll} 
& 2015 & 2016 & 2017 & 2018 & 2019 \\
Op stam & 37,51 & 41,40 & 38,23 & 41,39 & 32,93 \\
\hline Geveld & 52,18 & 63,09 & 61,37 & 44,10 & 62,01 \\
\hline Totaal & 37,96 & 42,36 & 38,94 & 41,46 & 33,13 \\
\hline
\end{tabular}

Bron: Bedrijveninformatienet, Wageningen Economic Research.

\section{Meer hout geoogst}

In 2019 is gemiddeld 3,35 $\mathrm{m}^{3}$ hout per ha bos geoogst (tabel 1.4); dat is $7 \%$ meer dan het gemiddelde van 3,12 $\mathrm{m}^{3}$ hout per ha bos in de vier voorgaande jaren (2015-2018). Omdat vrijwel al het hout op stam wordt verkocht, zijn de hiervoor genoemde gemiddelde houtprijzen praktisch gelijk aan de prijzen voor hout op stam.

Tabel 1.4 Volume van de houtverkopen ( $m^{3}$ per ha) naar verkoopwijze, 2015-2019

\begin{tabular}{lrrrrrr} 
& 2015 & 2016 & 2017 & 2018 & 2,19 \\
Op stam & 3,04 & 2,83 & 2,94 & 3,17 & 3,07 \\
\hline Geveld & 0,15 & 0,19 & 0,09 & 0,08 & 0,28 \\
\hline Totaal & 3,19 & 3,02 & 3,03 & 3,25 & 3,35 \\
\hline
\end{tabular}

Bron: Bedrijveninformatienet, Wageningen Economic Research.

Een klein deel van de houtopbrengsten bestaat uit de verkoop van hout als biomassa (stookhout). Het ging daarbij in de afgelopen vijf jaar om een jaarlijks bedrag van gemiddeld 7 euro per ha bos. Vanaf 2012 wordt ook het volume van deze houtverkopen opgevraagd en/of geschat. Dit volume steeg van gemiddeld 0,32 $\mathrm{m}^{3}$ per ha per jaar in de jaren 2014-2016 tot 0,51 $\mathrm{m}^{3}$ per ha per jaar in 2017-2018, maar bleef in 2019 beperkt tot 0,22 $\mathrm{m}^{3}$ per ha.

\section{$1.4 \quad$ Kostensoorten}

Gemiddelde kosten gelijk

De gemiddelde kosten van het bosbeheer van de particuliere bosbedrijven (met meer dan 50 ha bos) bedroegen 273 euro per ha in 2019, en lagen daarmee op het niveau van de twee voorgaande jaren (tabel 1.5).

Tabel 1.5 Kosten (euro per ha bos) naar kostensoorten, 2015-2019

\begin{tabular}{|c|c|c|c|c|c|}
\hline & 2015 & 2016 & 2017 & 2018 & 2019 \\
\hline Beheer, leiding en toezicht & 79 & 73 & 82 & 80 & 93 \\
\hline Arbeid uitvoerend & 53 & 51 & 61 & 57 & 43 \\
\hline Werktuigen en grondstoffen & 30 & 32 & 33 & 28 & 32 \\
\hline Heffingen en verzekeringen & 6 & 7 & 7 & 7 & 7 \\
\hline Totale kosten & 233 & 245 & 274 & 268 & 273 \\
\hline
\end{tabular}

Bron: Bedrijveninformatienet, Wageningen Economic Research.

De kosten van het personeel voor het uitvoerende werk (post 'arbeid uitvoerend') daalden ten opzichte van 2018, maar de kosten voor beheer, leiding en toezicht namen toe. Deze laatste post is samen met het werk door derden de belangrijkste kostenpost, met respectievelijk $34 \%$ en $29 \%$ van de kosten (figuur 1.2). Hierna volgen de posten arbeid uitvoerend (16\%), werktuigen en grondstoffen $(12 \%)$, heffingen en verzekeringen ( $3 \%)$ en overige kosten $(6 \%)$. 


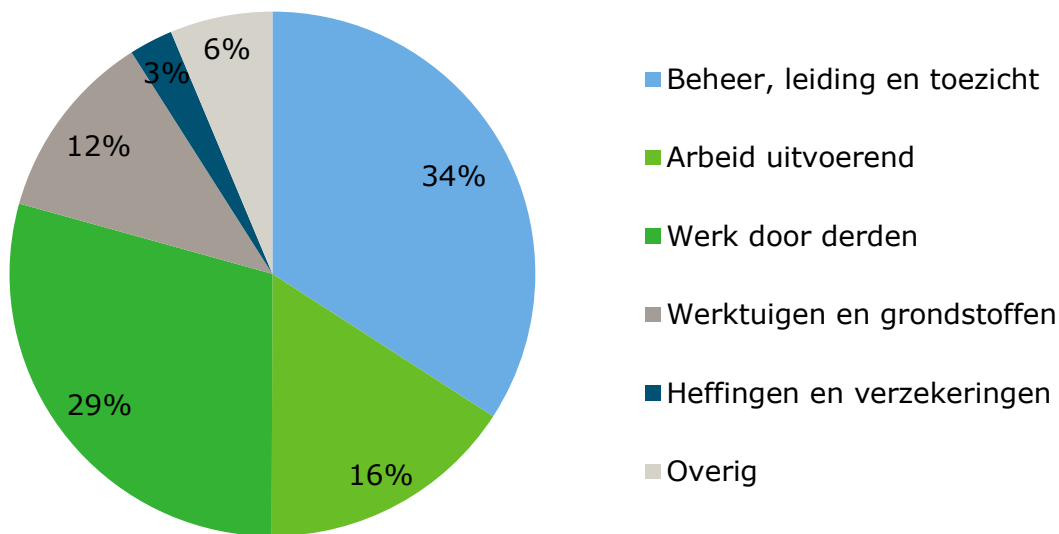

Figuur 1.2 Verdeling (\%) kosten naar kostensoorten, 2019

Bron: Bedrijveninformatienet, Wageningen Economic Research.

Een deel van het werk wordt door de eigenaar zelf uitgevoerd waarvoor een 'berekend loon' is opgenomen. De berekende vergoeding voor dit werk is opgenomen in de posten 'beheer, leiding en toezicht' en 'arbeid uitvoerend'. In 2019 is daarvoor gemiddeld 13 euro per ha bos in rekening gebracht, ofwel $5 \%$ van de totale kosten van het bosbeheer.

\section{$1.5 \quad$ Kostenplaatsen}

Toename algemene kosten

De diverse kostensoorten kunnen worden toegerekend aan maatregelen of activiteiten: de kostenplaatsen. De grootste post wordt gevormd door algemene kosten. In 2019 bedroegen de algemene kosten 118 euro per ha, ruim boven het gemiddelde niveau in de jaren 2015-2018 (tabel 1.6). Het overgrote deel (79\% in 2019) van de algemene kosten wordt gevormd door beheer, leiding en toezicht. Daarnaast bestaan de algemene kosten uit heffingen en verzekeringen en overige kosten (zoals voor administratieve dienstverlening).

Tabel 1.6 Kosten (euro per ha bos) naar kostenplaatsen, 2015-2019

\begin{tabular}{|c|c|c|c|c|c|}
\hline & 2015 & 2016 & 2017 & 2018 & 2019 \\
\hline Algemene kosten & 101 & 96 & 106 & 105 & 118 \\
\hline w.v. beheer, leiding en toezicht & 79 & 73 & 82 & 80 & 93 \\
\hline overig & 16 & 16 & 16 & 18 & 17 \\
\hline Bosverjonging & 20 & 22 & 25 & 16 & 23 \\
\hline Infrastructuur & 28 & 29 & 35 & 32 & 29 \\
\hline Vellingen & 15 & 27 & 27 & 37 & 34 \\
\hline Totaal & 233 & 245 & 274 & 268 & 273 \\
\hline
\end{tabular}

Bron: Bedrijveninformatienet, Wageningen Economic Research.

In 2019 lagen de totale kosten voor bosverjonging, onderhoud van infrastructuur en overig bosonderhoud op 121 euro per ha, tegen gemiddeld 126 euro per ha per ha in de jaren 2015-2018. De kosten voor de houtoogst in eigen beheer lagen in 2019 op 34 euro per ha (tabel 1.6); dat is vergelijkbaar met het bedrag in 2018, maar ruim boven het gemiddelde in de voorgaande jaren (gemiddeld 23 euro per ha in de periode 2015-2017). 


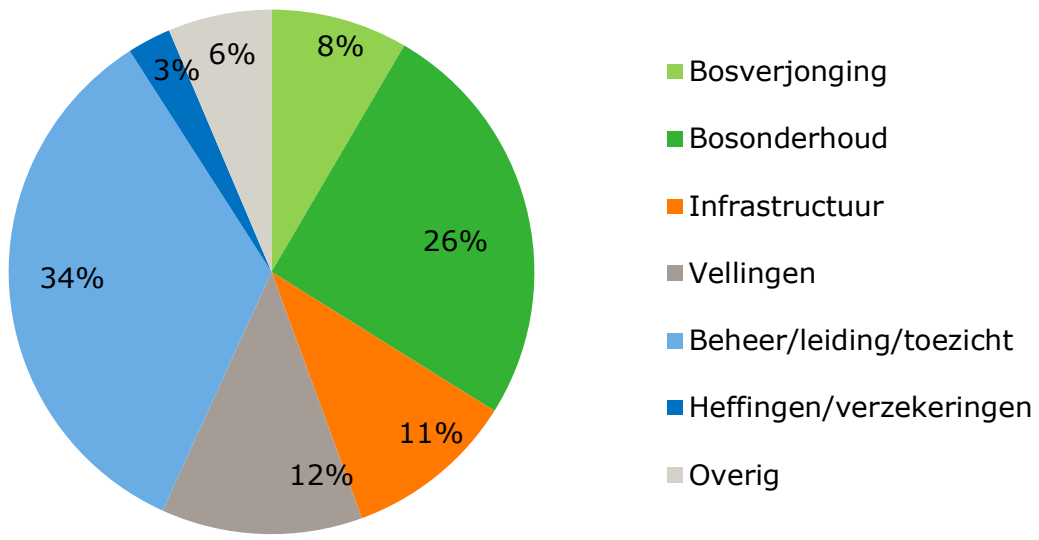

Figuur 1.3 Verdeling (\%) kosten naar kostenplaatsen, 2019 Bron: Bedrijveninformatienet, Wageningen Economic Research.

De kostenplaatsen 'Beheer/leiding/toezicht' (34\%) en 'Bosonderhoud' (26\%) hebben de grootste aandelen in de totale kosten (figuur 1.3).

\subsection{Spreiding in resultaten}

De resultaten van de bosbedrijven vertonen grote verschillen. In 2019 had $36 \%$ van de bedrijven een bedrijfsresultaat van minder dan -100 euro per ha, en $25 \%$ een resultaat van meer dan 100 euro per ha (tabel 1.7).

Tabel 1.7 Verdeling (\%) bedrijven en areaal bos naar bedrijfsresultaat, 2017-2019

\begin{tabular}{|c|c|c|c|c|c|c|}
\hline \multirow{2}{*}{$\begin{array}{l}\text { Bedrijfsresultaat } \\
\text { (euro/ha bos) }\end{array}$} & \multicolumn{2}{|c|}{2017} & \multicolumn{2}{|c|}{2018} & \multicolumn{2}{|c|}{2019} \\
\hline & Bedrijven $(\%)$ & Ha bos $(\%)$ & Bedrijven ( $\%$ ) & Ha bos ( $\%)$ & Bedrijven ( $\%)$ & Ha bos $(\%)$ \\
\hline$<-100$ & 36 & 27 & 33 & 25 & 36 & 27 \\
\hline-50 tot 0 & 5 & 8 & 9 & 14 & 9 & 13 \\
\hline 0 tot 50 & 15 & 13 & 12 & 26 & 15 & 20 \\
\hline$>100$ & 23 & 22 & 30 & 25 & 25 & 21 \\
\hline Totaal & 100 & 100 & 100 & 100 & 100 & 100 \\
\hline
\end{tabular}

Bron: Bedrijveninformatienet, Wageningen Economic Research.

In 2019 haalde $48 \%$ van de bedrijven een positief resultaat, tegen $49 \%$ in 2018 . De bedrijven die in 2019 uit de rode cijfers bleven, beheerden 45\% van het bosareaal; in 2018 was dit aandeel 56\%. 


\section{Resultaten naar bedrijfsgrootte}

\section{$2.1 \quad$ Bedrijfsresultaten}

Grote bedrijven boekten positief resultaat

Om een beeld te geven van de resultaten naar de grootte van het bosbezit zijn drie klassen bedrijven onderscheiden: klein (van 50 tot 100 ha), middelgroot ( 100 tot 250 ha) en groot ( 250 ha bos of meer). De kleine en middelgrote bedrijven boekten in 2019 een bedrijfsresultaat van respectievelijk min 54 en min 26 euro per ha bos, terwijl de grote bedrijven het jaar afsloten met een plus van 15 euro per ha (tabel 2.1).

Tabel 2.1 Resultaten (euro per ha bos per jaar) naar grootte bosareaal, 2015-2019

\begin{tabular}{l|rr|r|r|r} 
& \multicolumn{2}{c|}{50 tot 100 ha } & \multicolumn{1}{c|}{100 tot 250 ha } & 250 ha of meer \\
\cline { 2 - 7 } & $2015 / 2018$ & 2019 & $2015 / 2018$ & 2019 & $2015 / 2018$ \\
\hline Opbrengsten & 252 & 283 & 349 & 277 & 254 \\
\hline Kosten & 287 & 338 & 300 & 304 & 249 \\
\hline Bedrijfsresultaat & -35 & -54 & 49 & -26 & 30 \\
\hline Opbrengsten/kosten (\%) & 91 & 84 & 116 & 91 & 113 \\
\hline Inkomen uit het bosbedrijf & -6 & -22 & 72 & -7 & 34 \\
\hline
\end{tabular}

Bron: Bedrijveninformatienet, Wageningen Economic Research.

De verhouding tussen de opbrengsten en kosten in procenten (een andere maat voor de rentabiliteit) varieerde tussen $84 \%$ op de kleine bedrijven tot $106 \%$ op de grote bedrijven.

Ten opzichte van de gemiddelde resultaten in de vier voorgaande jaren (2015-2018) is het bedrijfsresultaat in alle drie de groepen bedrijven teruggelopen (tabel 2.1). De sterkste daling vond plaats op de middelgrote bedrijven door veel lagere opbrengsten. Op de kleine bedrijven stegen de kosten vrij sterk, die ten dele werden gecompenseerd door hogere opbrengsten. Het lagere resultaat op de grote bedrijven is een combinatie van iets hogere kosten en iets lagere opbrengsten.

Het inkomen uit het bosbedrijf - het bedrijfsresultaat plus de berekende vergoeding van de eigen arbeid - is op de middelgrote bedrijven van gemiddeld 72 euro per jaar in de jaren 2015-2018 omgeslagen in een min van 7 euro per ha (tabel 2.1).

De berekende vergoeding van de eigen arbeid per ha neemt af met de bedrijfsgrootte: in 2019 was die $9 \%$ van de totale kosten per ha op de kleine bedrijven, $6 \%$ op de middelgrote, en $1 \%$ op de grote bedrijven.

\section{Spreiding bedrijfsresultaten groot}

Gemiddeld genomen lopen de bedrijfsresultaten op bij een toenemende bedrijfsomvang (ha bos) (figuur 2.1): in de periode 2015-2019 boekte rond de helft van de kleine en middelgrote bedrijven een positief resultaat; voor de grote bedrijven was dat bijna $60 \%$. 


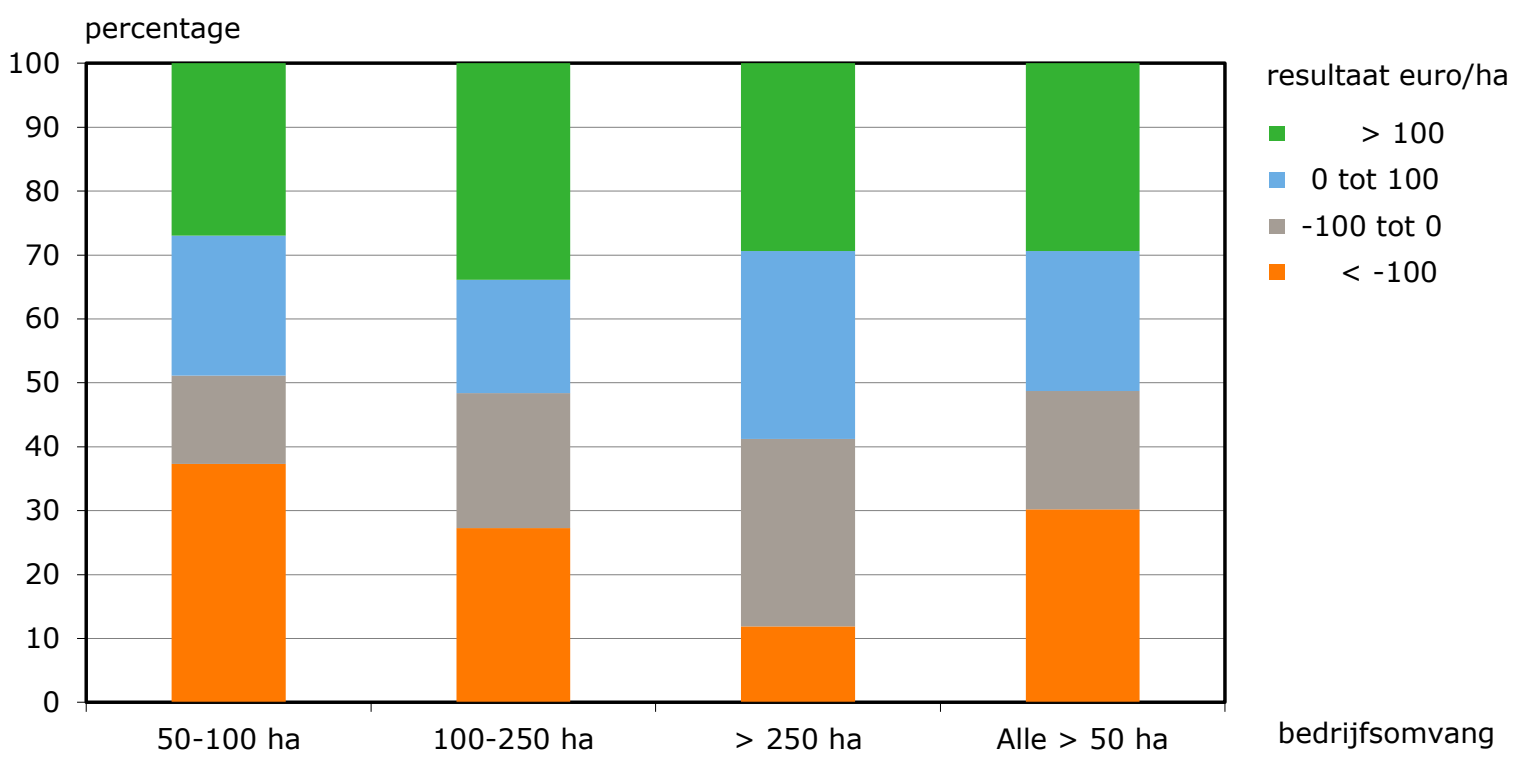

Figuur 2.1 Aandeel (\%) bedrijven naar bedrijfsresultaat en bedrijfsomvang, gemiddelde 2015-2019 Bron: Bedrijveninformatienet, Wageningen Economic Research.

\subsection{Opbrengsten}

Kleine bedrijven: hogere opbrengsten

De totale opbrengsten op de kleine bedrijven (50-100 ha bos) kwamen in 2019 uit op 283 euro per ha, ruim (12\%) boven het gemiddelde niveau in de periode 2015-2018 (tabel 2.2). Dat is geheel te danken aan de veel hogere houtopbrengsten, die de lagere subsidies ruimschoots goedmaakten. In 2019 bestonden de opbrengsten van de kleine bedrijven voor $61 \%$ uit houtopbrengsten, $26 \%$ uit subsidies en voor $13 \%$ uit andere opbrengsten (jachthuur, recreatie- en overige opbrengsten).

\section{Middelgrote bedrijven: lagere opbrengsten}

De totale opbrengsten van de middelgrote bedrijven (100-250 ha bos) daalden in 2019 tot 277 euro per ha (tabel 2.2), een vijfde lager dan het gemiddelde niveau in de vier voorgaande jaren (20152018). Dat komt vrijwel geheel door de lagere houtopbrengsten. Daarnaast namen ook de subsidies en andere opbrengsten (totaal van jachthuur, recreatie- en overige opbrengsten) af.

Het aandeel van de houtopbrengsten was op de middelgrote bedrijven 34\% in 2019 (tegen $43 \%$ gemiddeld in de jaren 2015-2018); de subsidies waren goed voor $45 \%$ van de opbrengsten, en de andere opbrengsten voor $21 \%$.

Tabel 2.2 Opbrengsten (euro per ha bos per jaar) naar grootte bosareaal, 2015-2019

\begin{tabular}{|c|c|c|c|c|c|c|}
\hline & \multicolumn{2}{|c|}{50 tot 100 ha } & \multicolumn{2}{|c|}{100 tot 250 ha } & \multicolumn{2}{|c|}{250 ha of meer } \\
\hline Hout & 125 & 174 & 149 & 95 & 131 & 114 \\
\hline geveld & 7 & 74 & 4 & 1 & 9 & 2 \\
\hline Beheersubsidie & 73 & 69 & 109 & 88 & 69 & 86 \\
\hline Jachthuur & 11 & 12 & 17 & 16 & 20 & 17 \\
\hline Recreatie & 20 & 18 & 22 & 30 & 11 & 10 \\
\hline Overig & 9 & 6 & 22 & 11 & 14 & 17 \\
\hline Totaal & 252 & 283 & 349 & 277 & 254 & 249 \\
\hline
\end{tabular}

Bron: Bedrijveninformatienet, Wageningen Economic Research. 
Grote bedrijven: gelijke opbrengsten

De grote bedrijven ( 250 ha bos of meer) haalden in 2019 een totale opbrengst van 249 euro per ha bos (tabel 2.2), vergelijkbaar met het gemiddelde niveau in de periode 2015-2018. Ook op de grote bedrijven daalden de houtopbrengsten, maar daar stonden hogere subsidies tegenover. In 2019 bestonden de opbrengsten op de grote bedrijven voor $46 \%$ uit houtopbrengsten, voor $36 \%$ uit subsidies en voor $18 \%$ uit andere opbrengsten (jachthuur, recreatie- en overige opbrengsten).

\subsection{Kosten}

Kleine bedrijven: hogere kosten

De totale kosten op de kleine bedrijven kwamen in 2019 uit op 338 euro per ha (tabel 2.3), 18\% hoger dan het gemiddelde niveau in de jaren 2015-2018. Deze toename houdt verband met de hogere houtopbrengsten (zie paragraaf 2.2). Vooral de kosten van het werk door derden namen toe, en in mindere mate die voor beheer, leiding en toezicht. In 2019 waren de kosten voor het werk door derden goed voor $42 \%$ van de totale kosten, tegen gemiddeld $29 \%$ in de jaren $2015-2018$. De post beheer, leiding en toezicht vormde $29 \%$ van de kosten. Verder werd $12 \%$ besteed aan het werk in eigen beheer (post arbeid uitvoerend) en $17 \%$ aan de overige posten (werktuigen en grondstoffen, heffingen en verzekeringen, en overige kosten).

Middelgrote bedrijven: gelijke kosten

De totale kosten op de middelgrote bedrijven bedroegen 304 euro per ha in 2019, vrijwel gelijk aan de gemiddelde kosten in de periode 2015-2018 (tabel 2.3). Ook de kosten voor de verschillende posten veranderden nauwelijks. In 2019 ging 36\% van de totale kosten op aan beheer, leiding en toezicht, $25 \%$ aan werk door derden, $18 \%$ aan arbeid uitvoerend en $21 \%$ aan de overige kostenposten (werktuigen en grondstoffen, heffingen en verzekeringen, en overige kosten).

Tabel 2.3 Kosten (euro per ha bos per jaar) naar kostensoorten en grootte bosareaal, 2015-2019

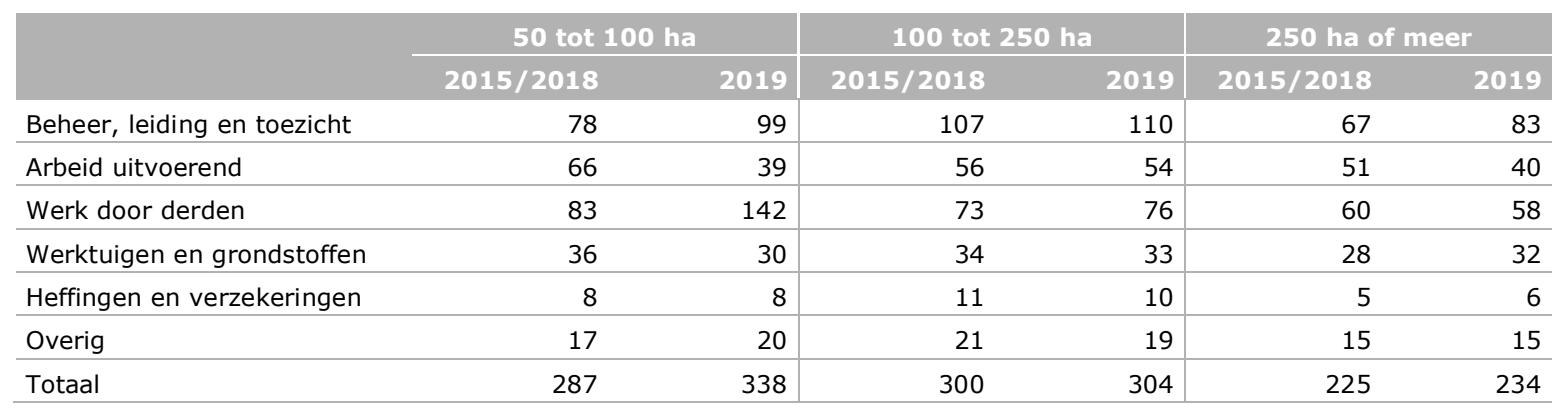

Bron: Bedrijveninformatienet, Wageningen Economic Research.

Grote bedrijven: stijging kosten beheer, leiding en toezicht

De totale kosten op de grote bedrijven stegen in 2019 iets ten opzichte van het gemiddelde niveau in de jaren 2015-2018 tot 234 euro per ha (tabel 2.3), ruim onder de kosten op de kleine en middelgrote bedrijven. De kosten voor beheer, leiding en toezicht stegen, terwijl die voor de post arbeid uitvoerend daalden. Het aandeel van de post beheer, leiding en toezicht kwam in 2019 uit op 35\%, en de post arbeid uitvoerend op 17\%. Verder ging 25\% van de kosten op aan werk door derden en $23 \%$ aan de overige posten (werktuigen en grondstoffen, heffingen en verzekeringen, en overige kosten).

De grote bedrijven hebben absoluut en relatief hogere kosten voor personeel dan de kleine en middelgrote bedrijven. Maar daardoor hebben ze lagere kosten voor de inhuur van derden, waaronder bijvoorbeeld een rentmeester, bosgroep of ingenieursbureau. Een deel van deze kosten valt onder de post beheer, leiding en toezicht. 


\section{Hogere algemene kosten}

In termen van kostenplaatsen (maatregelen of activiteiten) zijn de kosten voor beheer, leiding en toezicht de grootste post. Met de heffingen en verzekeringen en overige kosten die niet zijn toegerekend aan kostenplaatsen vormen ze de algemene kosten. Deze hadden in 2019 op de kleine bedrijven een aandeel van $38 \%$ in de totale kosten, op de middelgrote bedrijven was dat $46 \%$ en op de grote bedrijven $44 \%$.

Tabel 2.4 Kosten (euro per ha bos per jaar) naar kostenplaatsen en grootte bosareaal, 2015-2019

\begin{tabular}{|c|c|c|c|c|c|c|}
\hline & \multicolumn{2}{|c|}{50 tot 100 ha } & \multicolumn{2}{|c|}{100 tot 250 ha } & \multicolumn{2}{|c|}{250 ha of meer } \\
\hline & $2015 / 2018$ & 2019 & $2015 / 2018$ & 2019 & $2015 / 2018$ & 2019 \\
\hline Algemene kosten & 103 & 127 & 139 & 140 & 86 & 104 \\
\hline heffingen en verzekeringen & 8 & 8 & 11 & 10 & 5 & 6 \\
\hline overig & 17 & 20 & 22 & 20 & 15 & 15 \\
\hline Bosonderhoud & 93 & 79 & 80 & 78 & 66 & 62 \\
\hline Infrastructuur & 37 & 24 & 33 & 39 & 28 & 26 \\
\hline Vellingen & 35 & 70 & 27 & 25 & 24 & 24 \\
\hline Totaal & 287 & 338 & 300 & 304 & 225 & 234 \\
\hline
\end{tabular}

Bron: Bedrijveninformatienet, Wageningen Economic Research.

Op de kleine bedrijven verdubbelden in 2019 de kosten voor de vellingen in vergelijking met de gemiddelde kosten hiervan in de jaren 2015-2018. Deze stijging hing samen met de hogere houtopbrengsten (zie paragraaf 2.2). De vellingkosten op de kleine bedrijven waren in 2019 goed voor een vijfde van de totale kosten, tegen ongeveer een tiende op de middelgrote en grote bedrijven. Het aandeel van de kosten voor het overige bosbeheer (bosverjonging, bosonderhoud en infrastructuur) lag op de kleine bedrijven in 2019 op $41 \%$, tegen $45 \%$ op de middelgrote en grote bedrijven. 


\section{$3 \quad$ Resultaten naar regio}

\subsection{Bedrijfsresultaten}

\section{Lagere resultaten in Noordoost en Centrum}

In de regio's Noordoost en Centrum (zie bijlage 1, figuur B1.1) daalde het bedrijfsresultaat in 2019 tot respectievelijk min 14 euro en min 40 euro per ha (tabel 3.1). In Noordoost is de verslechtering van het resultaat ten opzichte van het gemiddelde in de jaren 2015-2018 vooral het gevolg van hogere kosten. In Centrum zijn het vooral de lagere opbrengsten die zorgden voor het lagere resultaat. In de regio Zuid verbeterde het bedrijfsresultaat in 2019 tot 38 euro per ha door hogere opbrengsten (en iets hogere kosten) in vergelijking met de gemiddelde uitkomsten in de periode 2015-2018.

Tabel 3.1 Resultaten (euro per ha bos per jaar) naar regio, 2015-2019

\begin{tabular}{lrr|r|r|r} 
& \multicolumn{2}{c}{ Noordoost } & Centrum & Zuid \\
\cline { 2 - 6 } & $2015 / 2018$ & 2019 & $2015 / 2018$ & 2019 & $2015 / 2018$ \\
\hline Opbrengsten & 305 & 294 & 305 & 262 & 190 \\
\hline Kosten & 280 & 307 & 287 & 301 & 170 \\
\hline Bedrijfsresultaat & 24 & -14 & 17 & -40 & 214 \\
\hline Opbrengsten/kosten (\%) & 109 & 96 & 107 & 87 & 112 \\
\hline Inkomen uit het bosbedrijf & 43 & 5 & 26 & -33 & 32 \\
\hline
\end{tabular}

Bron: Bedrijveninformatienet, Wageningen Economic Research.

In Zuid hoogste inkomen: 49 euro per ha

In de regio Noordoost daalde het inkomen uit het bosbedrijf - het bedrijfsresultaat plus de berekende vergoeding van de eigen arbeid - naar 5 euro per ha in 2019, en in Zuid tot min 33 euro per ha (tabel 3.1). In de regio Zuid steeg het inkomen tot 49 euro per ha, 17 euro per ha meer dan gemiddeld in 2015-2018.

\subsection{Opbrengsten}

Noordoost: lagere houtopbrengsten In de regio Noordoost waren de opbrengsten 294 euro per ha in 2019 (tabel 3.2), iets lager dan de gemiddelde jaaropbrengst in de periode 2015-2018. De lagere houtopbrengsten en andere opbrengsten (jachthuur, recreatie- en overige opbrengsten) werden deels gecompenseerd door een hoger bedrag aan subsidies. In 2019 bestonden de opbrengsten op de bedrijven in Noordoost voor $45 \%$ uit houtopbrengsten, voor $40 \%$ uit opbrengsten uit subsidies en voor $15 \%$ uit andere opbrengsten (jachthuur, recreatie- en overige opbrengsten).

\section{Centrum: lagere opbrengsten}

De opbrengsten op de bedrijven in de regio Centrum daalden in 2019 ten opzichte van het gemiddelde in de jaren 2015-2018 met 14\% naar 262 euro per ha (tabel 3.2). Zowel de houtopbrengsten als de totale subsidies als het totaal van andere opbrengsten (jachthuur, recreatie- en overige opbrengsten) vielen lager uit. De houtopbrengsten waren in 2019 goed voor 50\% van de totale opbrengsten, de subsidies voor $33 \%$ en de andere opbrengsten voor $17 \%$. 
Tabel 3.2 Opbrengsten (euro per ha bos per jaar) naar regio, 2015-2019

\begin{tabular}{|c|c|c|c|c|c|c|}
\hline & \multicolumn{2}{|c|}{ Noordoost } & \multicolumn{2}{|c|}{ Centrum } & \multicolumn{2}{|c|}{ Zuid } \\
\hline & $2015 / 2018$ & 2019 & $2015 / 2018$ & 2019 & $2015 / 2018$ & 2019 \\
\hline Hout & 150 & 132 & 150 & 132 & 86 & 89 \\
\hline geveld & 12 & 40 & 5 & 0 & 3 & 0 \\
\hline Beheersubsidie & 80 & 102 & 89 & 70 & 64 & 69 \\
\hline Jachthuur & 10 & 9 & 29 & 25 & 14 & 16 \\
\hline Recreatie & 16 & 15 & 9 & 11 & 21 & 28 \\
\hline Overig & 23 & 20 & 13 & 7 & 4 & 10 \\
\hline Totaal & 305 & 294 & 305 & 262 & 190 & 214 \\
\hline
\end{tabular}

Bron: Bedrijveninformatienet, Wageningen Economic Research.

Zuid: hogere opbrengsten

In de regio Zuid stegen de opbrengsten tot 214 euro per ha in $2019,13 \%$ hoger dan het gemiddelde van 2015-2018 (tabel 3.2). Dat is in hoofdzaak te danken aan de stijging van de andere opbrengsten (jachthuur, recreatie- en overige opbrengsten). De totale opbrengsten bestonden in 2019 voor $42 \%$ uit houtopbrengsten, voor $33 \%$ uit subsidies en voor $25 \%$ uit andere opbrengsten.

\subsection{Kosten}

Noordoost: hogere kosten

De kosten op de bedrijven in de regio Noordoost kwamen in 2019 uit op 307 euro per ha (tabel 3.3), $10 \%$ hoger dan het gemiddelde niveau in de jaren 2015-2018. De kosten voor de post beheer, leiding en toezicht, en de post werk door derden stegen, terwijl die voor het personeel voor het uitvoerende werk (post arbeid uitvoerend) daalden. De post beheer, leiding en toezicht was in 2019 goed voor $34 \%$ van de totale kosten; $45 \%$ ging naar de posten arbeid uitvoerend en werk door derden, en $21 \%$ naar de overige posten (werktuigen en grondstoffen, heffingen en verzekeringen en overige kosten).

Centrum: iets hogere kosten

In de regio Centrum lagen de kosten met 301 euro per ha in 2019 iets (5\%) boven het gemiddelde niveau in de jaren 2015-2018 (tabel 3.3). Ook in deze regio stegen de kosten voor de post beheer, leiding en toezicht, en de post werk door derden stegen, terwijl die voor het personeel voor het uitvoerende werk (post arbeid uitvoerend) daalden. De post beheer, leiding en toezicht was in 2019 goed voor $29 \%$ van de totale kosten; $49 \%$ ging naar de posten arbeid uitvoerend en werk door derden, en $22 \%$ naar de andere posten (werktuigen en grondstoffen, heffingen en verzekeringen en overige kosten).

Tabel 3.3 Kosten (euro per ha bos per jaar) naar kostensoorten en regio, 2015-2019

\begin{tabular}{|c|c|c|c|c|c|c|}
\hline & \multicolumn{2}{|c|}{ Noordoost } & \multicolumn{2}{|c|}{ Centrum } & \multicolumn{2}{|c|}{ Zuid } \\
\hline Beheer, leiding en toezicht & 82 & 105 & 74 & 88 & 79 & 79 \\
\hline Werk door derden & 73 & 89 & 78 & 89 & 44 & 53 \\
\hline Werktuigen en grondstoffen & 36 & 35 & 36 & 40 & 16 & 15 \\
\hline Overig & 18 & 20 & 20 & 19 & 10 & 10 \\
\hline Totaal & 280 & 307 & 287 & 301 & 170 & 176 \\
\hline
\end{tabular}

Bron: Bedrijveninformatienet, Wageningen Economic Research. 


\section{Zuid: kosten ongeveer gelijk}

De kosten op de bedrijven in regio Zuid lagen in 2019 op 176 euro per ha (tabel 3.3), ongeveer op het gemiddelde niveau in de jaren 2015-2018. De totale kosten op de bedrijven in Zuid zijn veel lager dan in de andere twee regio's. In Zuid zijn relatief veel kosten gaan zitten in beheer, leiding en toezicht: $45 \%$ van de totale kosten in 2019. De kosten van het terreinbeheer door derden en het eigen personeel waren goed voor $37 \%$, en de andere kosten (werktuigen en grondstoffen, heffingen en verzekeringen en overige kosten) voor $18 \%$ van de totale kosten.

Centrum investeerde bovengemiddeld in bosonderhoud

Naar kostenplaatsen (maatregelen of activiteiten) zijn de kosten voor beheer, leiding en toezicht de grootste kostenpost in alle drie de regio's (tabel 3.4). Met de heffingen en verzekeringen en overige kosten die niet zijn toegerekend aan kostenplaatsen vormen ze de algemene kosten. Het aandeel van de algemene kosten in de totale kosten liep in 2019 uiteen van 38\% in Centrum, 43\% in Noordoost, tot $55 \%$ in regio Zuid.

Tabel 3.4 Kosten (euro per ha bos per jaar) naar kostenplaatsen en regio, 2015-2019

\begin{tabular}{|c|c|c|c|c|c|c|}
\hline & \multicolumn{2}{|c|}{ Noordoost } & \multicolumn{2}{|c|}{ Centrum } & \multicolumn{2}{|c|}{ Zuid } \\
\hline & $2015 / 2018$ & 2019 & $2015 / 2018$ & 2019 & $2015 / 2018$ & 2019 \\
\hline Algemene kosten & 107 & 133 & 101 & 114 & 96 & 97 \\
\hline heffingen en verzekeringen & 8 & 8 & 6 & 7 & 7 & 7 \\
\hline overig & 18 & 20 & 20 & 20 & 10 & 10 \\
\hline Bosonderhoud & 66 & 65 & 106 & 100 & 49 & 36 \\
\hline Infrastructuur & 36 & 27 & 40 & 36 & 12 & 22 \\
\hline Vellingen & 43 & 56 & 21 & 20 & 7 & 15 \\
\hline Totaal & 280 & 307 & 287 & 301 & 170 & 176 \\
\hline
\end{tabular}

Bron: Bedrijveninformatienet, Wageningen Economic Research.

In de regio Noordoost stegen de vellingkosten in 2019 in vergelijking met het gemiddelde niveau in de jaren 2015-2015 (tabel 3.4), en daalden de kosten voor het overige bosbeheer (bosverjonging, bosonderhoud en infrastructuur). De vellingkosten waren in 2019 in Noordoost goed voor $18 \%$ van de totale kosten, en het overige bosbeheer voor 38\%. In Zuid had het overig bosbeheer een vergelijkbaar deel van de kosten, maar in de regio Centrum lag dat ruim daarboven (55\% in 2019). 


\section{$4 \quad$ Resultaten op lange termijn}

\subsection{Bedrijfsresultaten}

\section{Pieken en dalen}

In dit hoofdstuk over de lange termijn zijn de resultaten gecorrigeerd voor inflatie. Dit is gedaan met behulp van de prijsmutatie van het bruto binnenlands product (bbp, zie nationale rekeningen van het CBS). Het gemiddeld reëel bedrijfsresultaat van particuliere bosbedrijven (groter dan 50 ha) laat over de gehele waarnemingsperiode van 1975-2019 pieken en dalen zien (figuur 4.1). In de periode 19751990 was het gemiddelde resultaat 32 euro per ha negatief, maar werd het verlies sterk verminderd. In de jaren 1991-2005 - een meer stabiele periode - werd gemiddeld 22 euro verlies geleden. Vanaf 2006 zijn op drie jaar na alle jaren met een positief resultaat afgesloten; gemiddeld is tussen 2006 en 2019 een positief resultaat geboekt van 34 euro per ha bos. Zo bezien is er een positieve trend in de resultaten, maar in de laatste periode 2006-2019 was het gemiddelde resultaat van 2019 het laagst.

Fluctuerende houtopbrengsten

Verschillende factoren leiden tot pieken en dalen in het gemiddelde bedrijfsresultaat. In het stormjaar 1990 had de niet-geplande toename van het volume van de houtoogst eenmalig een hoger bedrijfsresultaat per ha tot gevolg. Ook in 1994 en 1995 was er een tijdelijke opleving door een hoger volume van de houtoogst. Toen maakten veel boseigenaren op het laatste moment nog gebruik van de aflopende herplantsubsidie. Nog rooskleuriger waren de resultaten in de jaren 2006-2007 en 20102015, vooral dankzij de hoge houtopbrengsten.

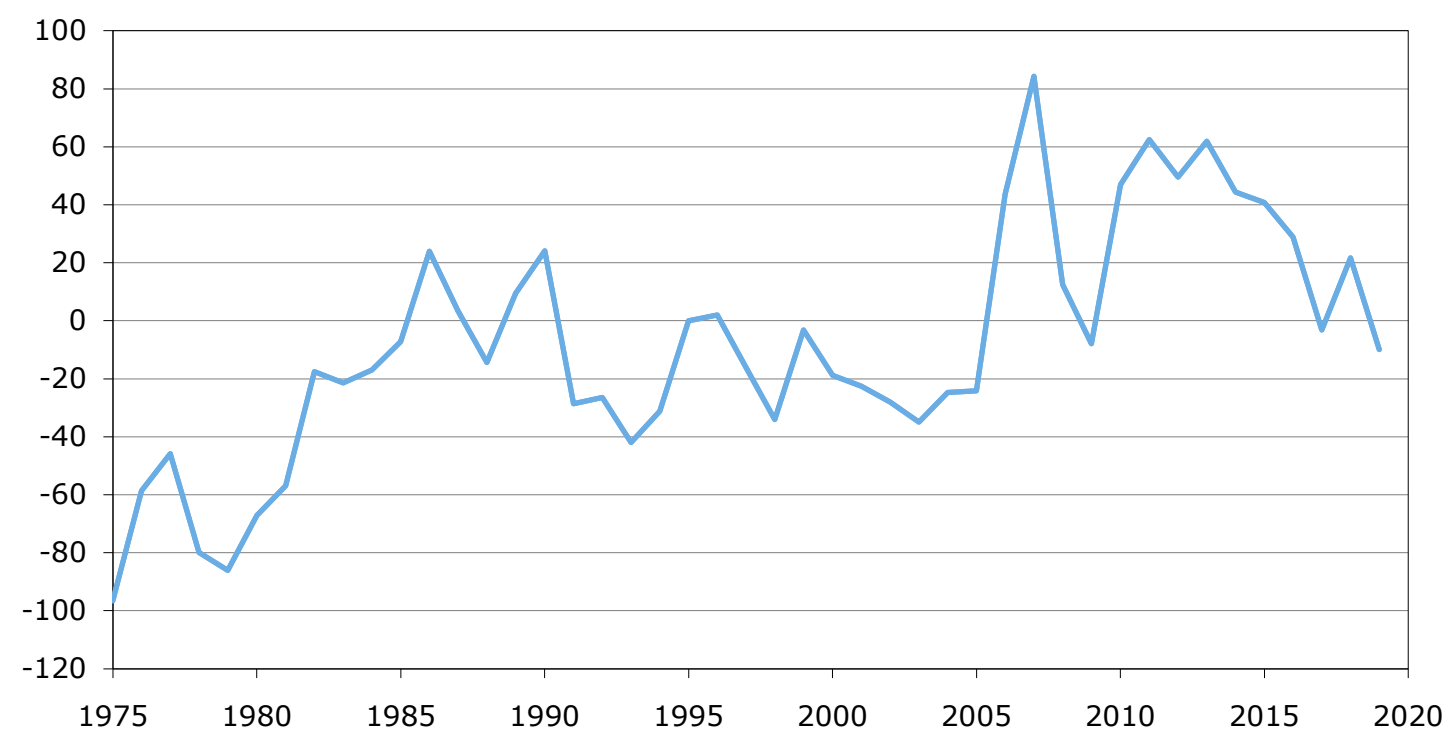

Figuur 4.1 Gemiddeld reëel bedrijfsresultaat per ha bos (in euro's van 2019), 1975-2019 Bron: Bedrijveninformatienet, Wageningen Economic Research.

\subsection{Kosten en opbrengsten}

Daling van kosten en opbrengsten

De bosbedrijven hebben de reële kosten in de afgelopen decennia met $40 \%$ teruggebracht, van gemiddeld 450 euro per ha per jaar tussen $1975-1980$ tot 270 euro in de laatste vijf jaar. De grootste 
daling vond plaats vóór 1990. De ontwikkeling van de opbrengsten verliep tot 2005 volgens het patroon van de kosten; daarna stegen de houtopbrengsten onder invloed van de hogere houtprijzen. De totale reële opbrengsten lagen in de jaren 1975-1980 op gemiddeld 380 euro per ha per jaar en in de laatste vijf jaar op circa 290 euro per ha, bijna een kwart lager. Tussen 2001 en 2005 werd een dieptepunt in opbrengsten bereikt van ongeveer 240 euro per ha per jaar (figuur 4.2).

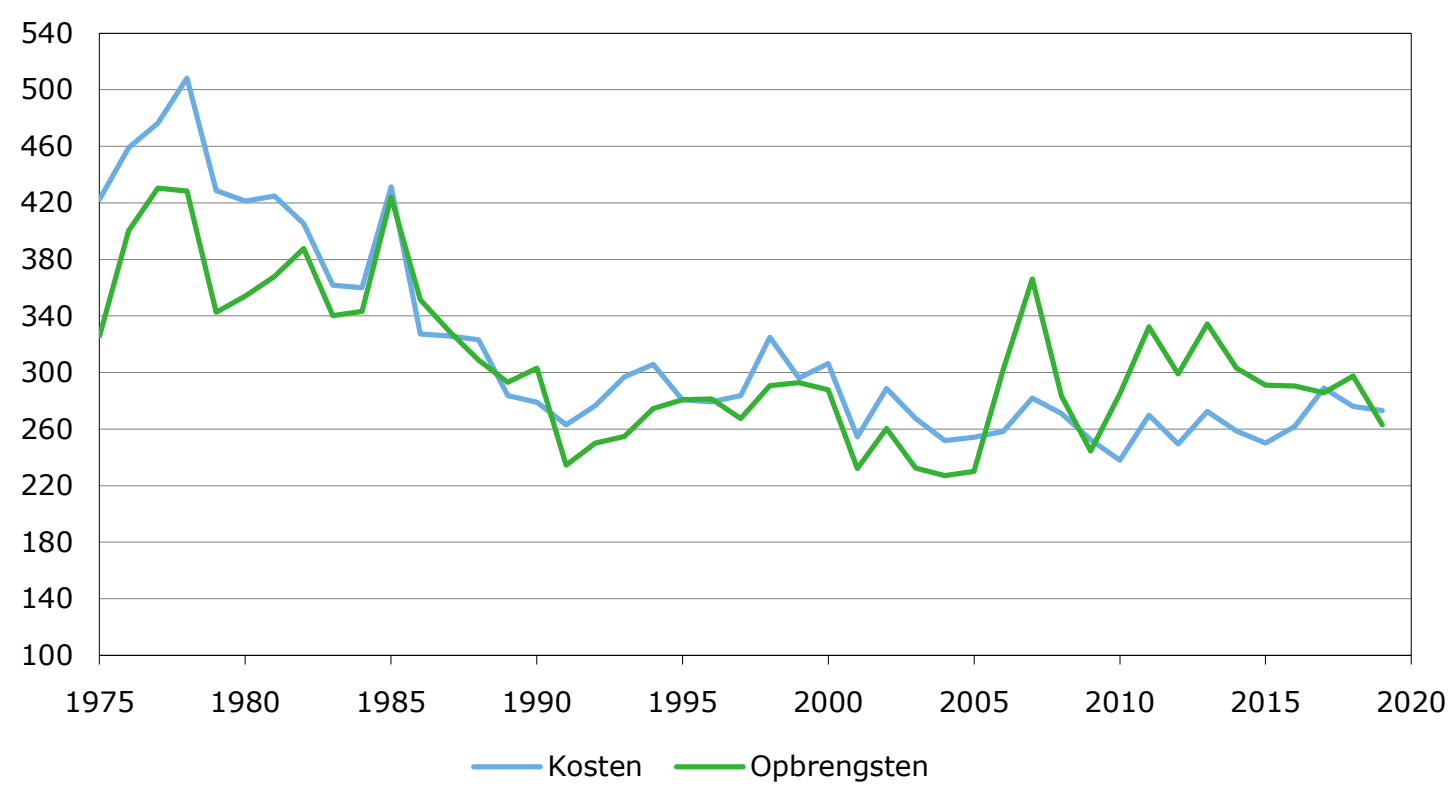

Figuur 4.2 Reële kosten en opbrengsten per ha bos (in euro's van 2019), 1975-2019 Bron: Bedrijveninformatienet, Wageningen Economic Research.

Herstel van houtopbrengsten

De reële houtopbrengsten schommelden tot 1990 tussen 120 à 140 euro per ha per jaar, zakten tot 60 euro in de jaren 2003-2005, maar herstelden daarna tot gemiddeld 140 euro per jaar in de afgelopen vijf jaar. Door met voortschrijdende gemiddelden te werken worden de trends beter zichtbaar (figuur 4.3).

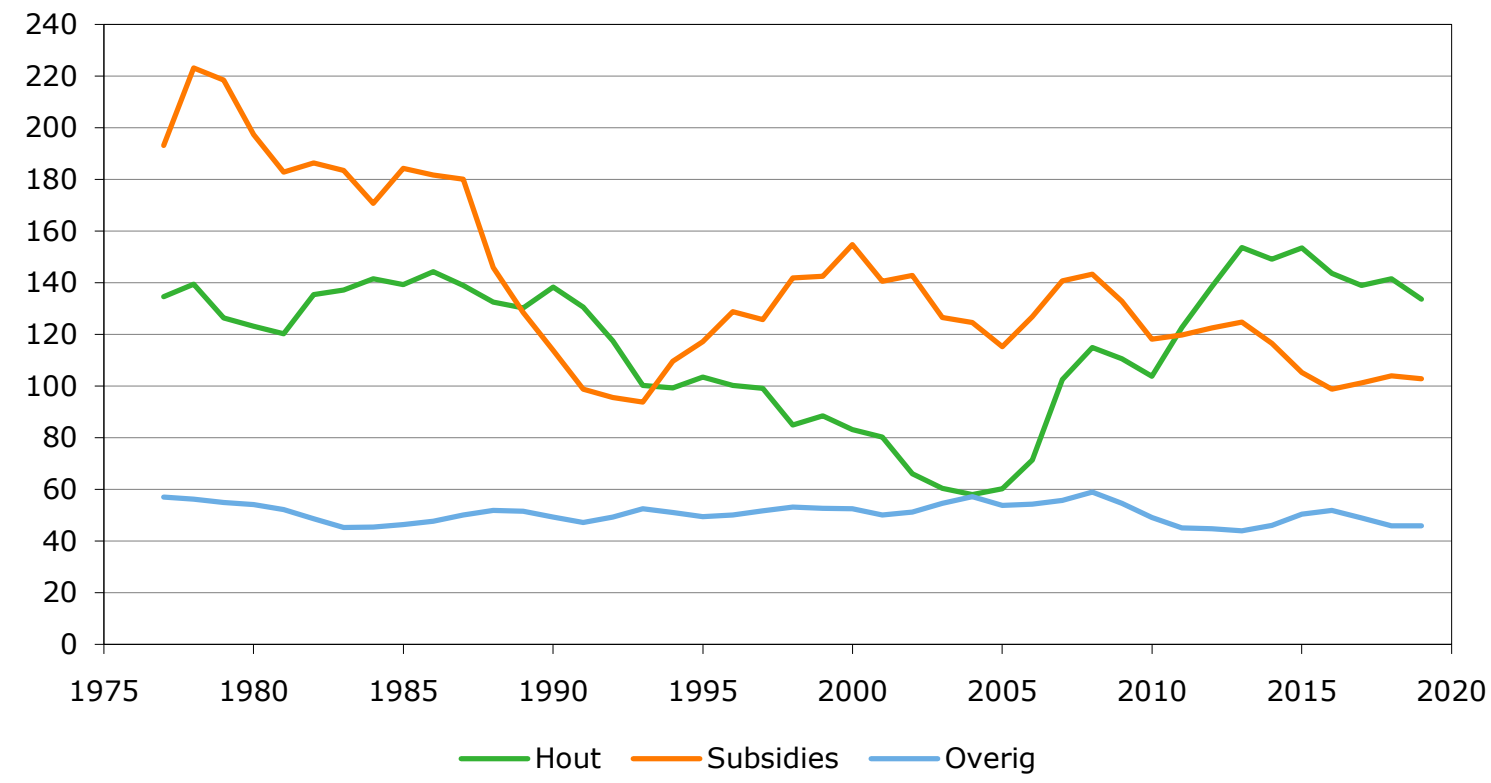

Figuur 4.3 Reële opbrengsten per ha bos (in euro's van 2019), voortschrijdend driejaarlijks gemiddelde 1977-2019

Bron: Bedrijveninformatienet, Wageningen Economic Research. 


\section{Wisselend verloop van subsidies}

Van de tweede helft van de jaren zeventig tot het begin van de jaren negentig daalden de reële subsidies van meer dan 200 euro tot onder de 100 euro per ha bos per jaar (figuur 4.3). Daarna trad een gedeeltelijk herstel op tot rond de eeuwwisseling (ruim 140 euro). De piek rond de eeuwwisseling heeft onder meer te maken met de verstrekte subsidies in die periode op basis van de Regeling effectgerichte maatregelen in bossen en natuurterreinen (EGM), een instrument voor het uitvoeren van het Overlevingsplan Bos en Natuur (OBN). Daarnaast waren er ook wat meer incidentele bijdragen (overige subsidies) van andere overheden (zoals provincies). In de meest recente jaren zijn de subsidies net iets boven de 100 euro per ha per jaar uitgekomen. De overige reële bedrijfsopbrengsten lagen in al die jaren tussen 40 en 60 euro per ha bos per jaar.

\subsection{Houtprijzen en oogstvolume}

In de waarnemingsperiode daalde de reële houtopbrengst per ha sterk tot 2005, maar daarna trad een fors herstel op (figuur 4.4). Hierachter gingen uiteenlopende volume- en prijsontwikkelingen schuil.

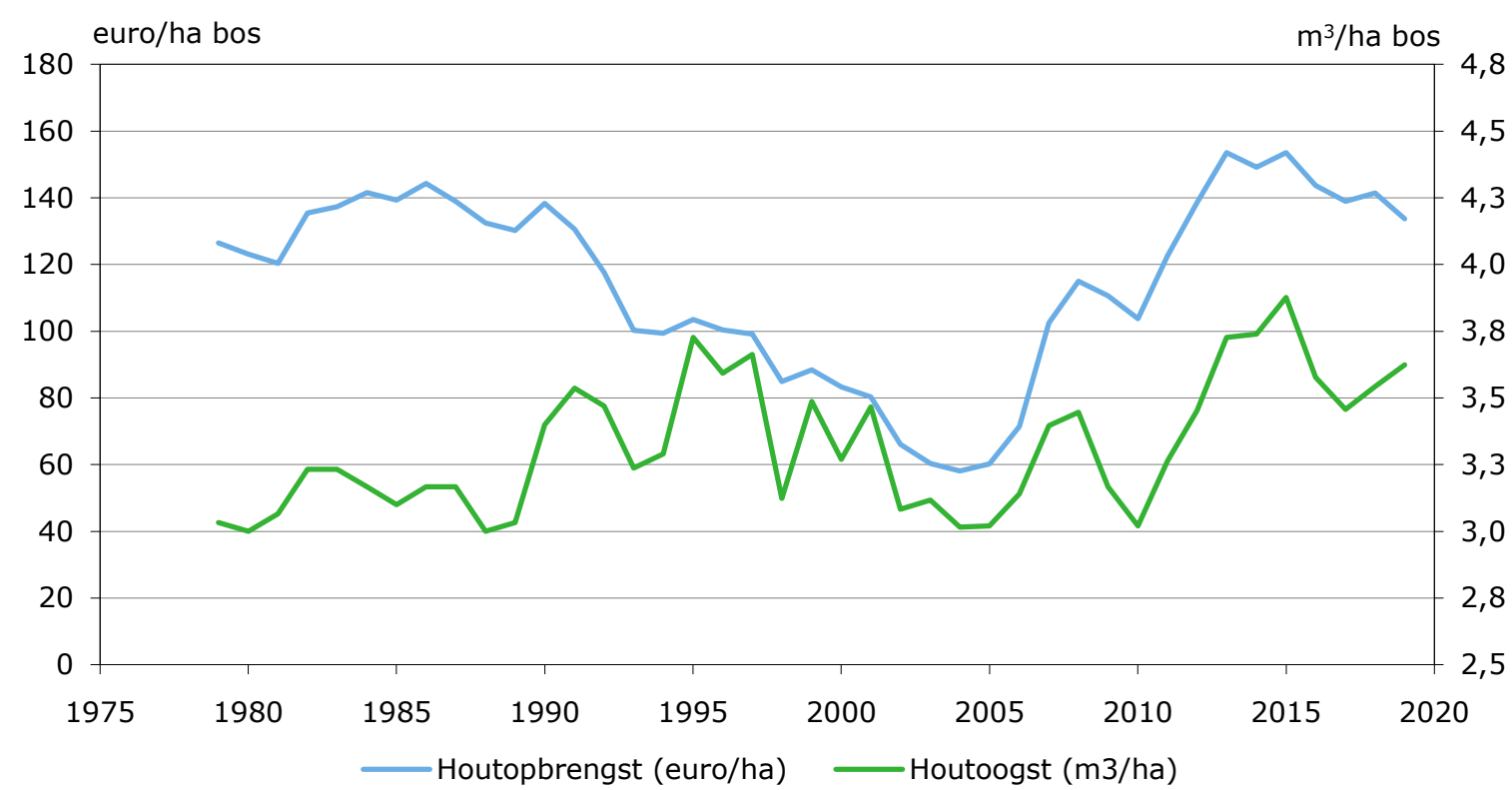

Figuur 4.4 Houtoogst ( $\mathrm{m}^{3}$ per ha) en reële houtopbrengsten per ha bos (in euro's van 2019), voortschrijdend driejaarlijks gemiddelde 1979-2019

Bron: Bedrijveninformatienet, Wageningen Economic Research.

Volume houtoogst zelden hoger dan $4 \mathrm{~m}^{3}$ per ha

Het volume van de houtoogst nam af van gemiddeld $3,5 \mathrm{~m}^{3}$ per ha in de eerste helft van de jaren negentig tot $3,0 \mathrm{~m}^{3}$ per ha in 2002. Dat hield verband met het wegvallen van de herplantsubsidie (per 1 januari 1994) en de sterke daling van de reële houtprijzen. De eindvelling verdween, terwijl dit niet werd gecompenseerd door meer dunning. Door het veranderde bosbeheer nam de houtvoorraad toe en verouderde de leeftijdsopbouw van het bos. Met de stijging van de houtprijzen na 2005 is het oogstvolume toegenomen tot gemiddeld 3,5 $\mathrm{m}^{3}$ per ha (2005-2019). Op de bosbedrijven is sinds 1975 slechts in enkele jaren meer geoogst dan $4 \mathrm{~m}^{3}$ per ha: 4,1 $\mathrm{m}^{3}$ in 1990 (stormjaar), 4,4 $\mathrm{m}^{3}$ in 1995 (aflopen herplantsubsidie), 4,1 $\mathrm{m}^{3}$ in 1999 en 4,2 $\mathrm{m}^{3}$ in 2013. Overigens zijn deze uitschieters niet te zien in figuur 4.4 doordat driejaarlijkse gemiddelden zijn weergegeven. 
Houtprijs internationaal bepaald

De gemiddelde reële houtprijs in Nederland daalde na de jaren tachtig sterk en bereikte een dieptepunt in 2004. Daarna steeg de prijs en was in 2010 terug op het niveau van de jaren tachtig.

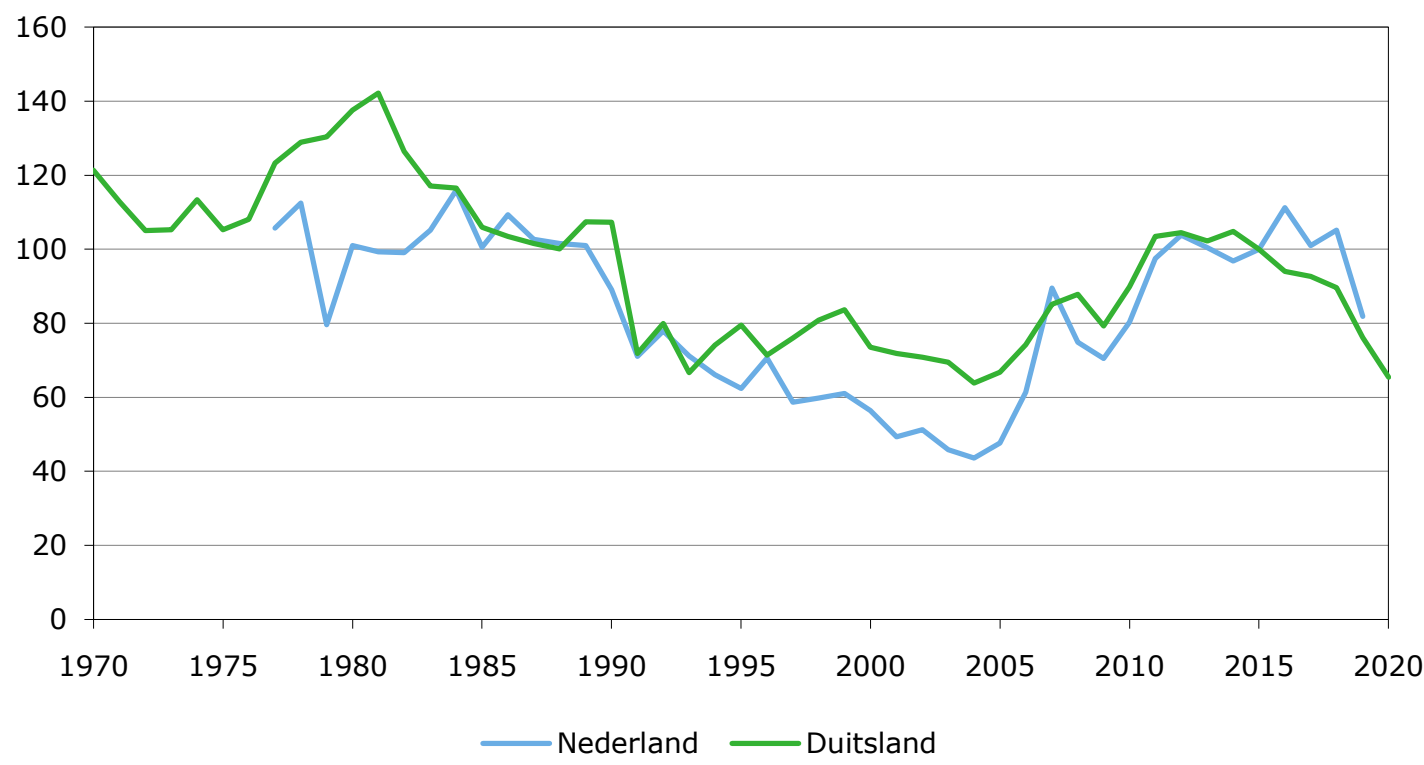

Figuur 4.5 Ontwikkeling reële houtprijs (2015=100), 1970-2020

De (geïndexeerde) houtprijs voor Nederland loopt tot 2019; die van Duitsland is ook beschikbaar voor 2020

Bron: OECD, Statistisches Bundesamt; Bedrijveninformatienet, Wageningen Economic Research.

In figuur 4.5 is de ontwikkeling van de reële houtprijs in Nederland (vanaf 1977) en het grote buurland en handelspartner Duitsland (prijsverloop vanaf 1970) weergegeven. De ontwikkelingen lopen in grote lijnen gelijk op, wat illustreert dat er voor hout een internationale markt is. 


\section{Bijlage 1 Verantwoording}

\section{B1.1 Doel en opzet monitor particuliere bosbouw}

Deze jaarlijkse publicatie over de Nederlandse particuliere bosbouw behandelt de resultaten, opbrengsten en kosten van bedrijven. Dit gebeurt onder meer ten behoeve van het beleid van de overheid (nationaal en regionaal), de Vereniging van Bos- en Natuurterreineigenaren (VBNE) en de eigenaren en beheerders van particuliere bosbedrijven.

Het rapport beschrijft de bedrijfsresultaten per hectare van alle bedrijven groter dan 50 ha (hoofdstuk 1), de bedrijfsresultaten naar bedrijfsgrootte (hoofdstuk 2) en de bedrijfsresultaten naar regio (hoofdstuk 3 ). In het afsluitende hoofdstuk 4 worden de ontwikkelingen van de particuliere bosbouw op lange termijn belicht. Voor de resultaten van de kleinere bedrijven ( 5 tot 25 ha en 25 tot 50 ha) wordt verwezen naar bijlage 2.

Deze bijlage geeft informatie over de omvang en samenstelling van de groep particuliere bosbedrijven (paragraaf B1.2) en over de deelnemers aan het Informatienet particuliere bosbedrijven van Wageningen Economic Research (paragraaf B1.3). Ten slotte worden de economische begrippen van de publicatie toegelicht (paragrafen B1.4 tot en met B1.7).

\section{B1.2 Particuliere bosbedrijven}

Particuliere bosbezittingen

Tot de opheffing van het Bosschap - het bedrijfschap voor bos en natuur - waren alle eigenaren van minimaal 5 ha bos verplicht geregistreerd. Daarbij werd onderscheid gemaakt tussen bosbezit in publieke hand, zoals de boseigendommen van het Rijk (waaronder Staatsbosbeheer, het Rijksvastgoedbedrijf (RVB), Defensie), provincies, waterschappen en gemeenten, en bosbezit in private handen.

De populatie van het Informatienet particuliere bosbedrijven van Wageningen Economic Research wordt gevormd door de private boseigenaren, met uitzondering van de natuurbeschermingsorganisaties. Volgens de meest recente data van het Bosschap uit 2012 zijn er 1.520 van dergelijke bedrijven in Nederland, met een bosbezit van in totaal bijna 63.000 ha (tabel B1.1). Dat is ongeveer 17\% van het bosareaal in Nederland.

Tabel B1.1 Particuliere bosbezittingen naar oppervlakte en regio, 2012

\begin{tabular}{|c|c|c|}
\hline & Aantal bedrijven & Bosareaal (ha) \\
\hline \multicolumn{3}{|l|}{ Oppervlakte } \\
\hline 5 tot 25 ha & 904 & 10.328 \\
\hline 25 tot 50 ha & 219 & 7.517 \\
\hline 50 tot 100 ha & 131 & 8.850 \\
\hline 100 tot 250 ha & 70 & 10.315 \\
\hline 250 ha en meer & 40 & 21.747 \\
\hline \multicolumn{3}{|l|}{ Regio } \\
\hline Noordoost & 637 & 25.060 \\
\hline Centrum & 370 & 18.645 \\
\hline Zuid & 357 & 15.052 \\
\hline \multicolumn{3}{|l|}{ Subtotalen } \\
\hline Doelpopulatie monitor & 1.364 & 58.757 \\
\hline Overig Nederland & 156 & 3.996 \\
\hline Totaal & 1.520 & 62.754 \\
\hline
\end{tabular}

Bron: Bosschap, bewerking Wageningen Economic Research. 
Volgens de laatste afgeronde nationale bosinventarisatie (Schelhaas et al., 2014) is het Nederlandse bosareaal ruim 373.000 ha. Hiervan is circa 181.000 ha (48\%) publiek bezit, 72.000 ha (19\%) in handen van natuurbeschermingsorganisaties (inclusief Natuurmonumenten), en ongeveer 121.000 ha privaat bezit. Het private bezit is georganiseerd in verschillende rechtsvormen: bedrijf, landgoed, overig particulier georganiseerd, privé.

Het verschil tussen het privaat bezit volgens het Bosschap ( 63.000 ha) en de bosinventarisatie (121.000 ha) heeft vooral te maken met de registratiegrens van 5 ha voor het Bosschap. Verder kunnen de gehanteerde bosdefinities en een niet volledige registratie van het Bosschap een rol spelen.

Indeling populatie naar omvang bosbezit en regio

Bij de opzet van het Informatienet is de populatie ingedeeld ('gestratificeerd') naar omvang van het bosbezit en de regionale ligging van de bedrijven, twee belangrijke kenmerken voor het onderzoek naar de bedrijfsuitkomsten. Van 1975 tot 1989 bestond de populatie uit bedrijven met meer dan 50 ha bos; in 1989 is de ondergrens verlaagd naar 5 ha (ondergrens van het register van het Bosschap). Dit is gedaan omdat het toenmalige ministerie van LNV en het Bosschap inzicht wilden verkrijgen in de resultaten van alle geregistreerde bedrijven. De bedrijven zijn ingedeeld in vijf oppervlakteklassen (zie tabel B1.2): 5-25 ha, 25-50 ha, 50-100 ha 100-250 ha en 250 ha en meer.

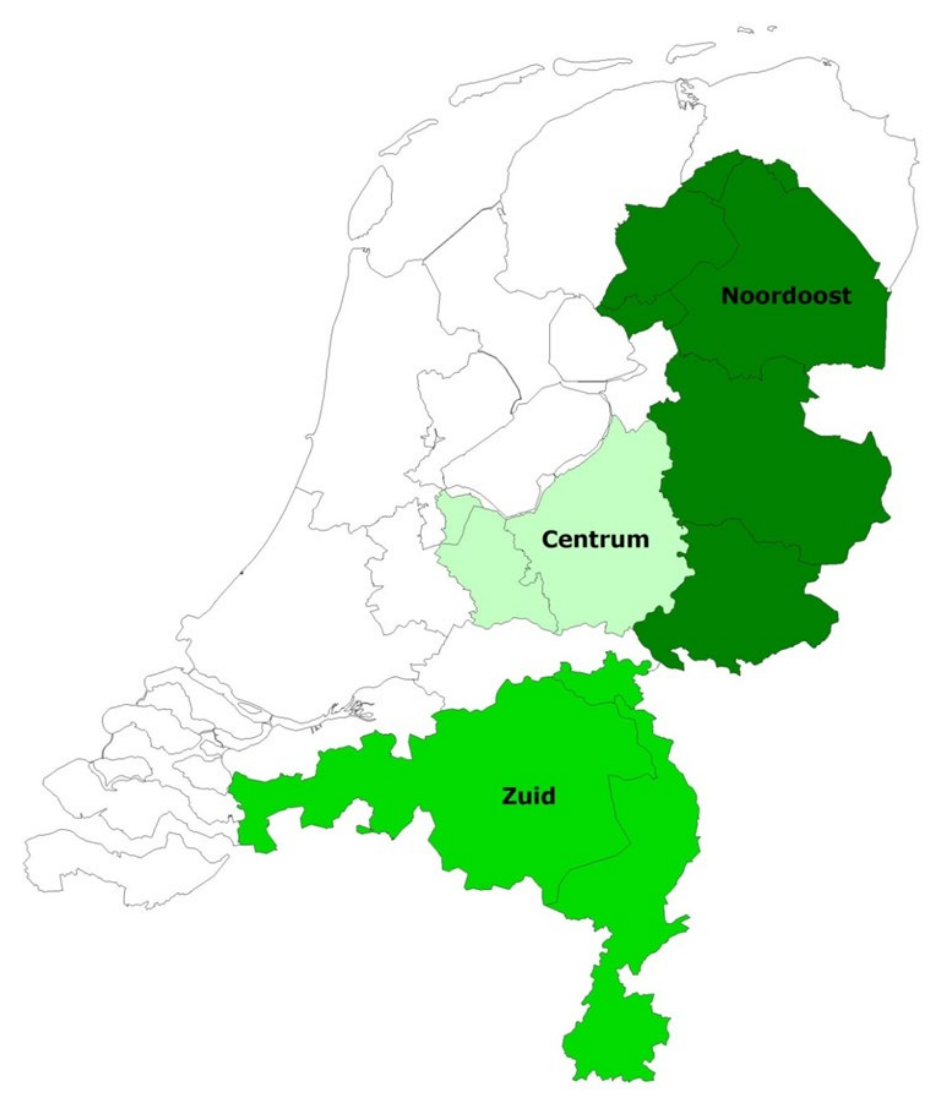

Figuur B1.1 Regio-indeling (gebaseerd op de Derde Nederlandse Bosstatistiek van het CBS)

Het tweede criterium - regionale ligging van de particuliere bosbedrijven - is gebaseerd op de Derde Nederlandse Bosstatistiek. De daarin voorkomende acht gebieden zijn samengevoegd tot vier regio's (figuur B1.1).

Deze indeling is vanaf 1975 gelijk gebleven. De regio's zijn:

- Noordoost: ten oosten en ten noorden van de IJssel, met uitzondering van de noordelijke klei- en laagveengebieden

- Centrum: Veluwe, Utrechtse Heuvelrug en Gooi

- Zuid: Noord-Brabant en Limburg, met uitzondering van het rivierengebied

- Overig Nederland. 
Uit de weinig bosrijke regio 'Overig Nederland' is geen steekproef getrokken, zodat deze regio in het rapport verder buiten beschouwing blijft. Ook in de uitkomsten per grootteklasse en voor alle bedrijven zijn de bedrijven uit Overig Nederland niet opgenomen. Hiermee komt de uiteindelijke doelpopulatie van het Informatienet uit op 1.364 particuliere bosbedrijven met een areaal bos van 58.757 ha in 2012 (tabel B1.1).

\section{B1.3 Deelnemers aan het Informatienet}

De deelnemers aan het Informatienet zijn gekozen met behulp van een steekproef uit de hiervoor genoemde doelpopulatie, die is verdeeld over vijftien subgroepen: de combinatie van vijf oppervlakteklassen en drie regio's.

Tabel B1.2 Steekproefdichtheid naar oppervlakte en regio, 2019

\begin{tabular}{|c|c|c|c|}
\hline & $\begin{array}{l}\text { Aantal steek- } \\
\text { proefbedrijven }\end{array}$ & $\begin{array}{r}\text { Steekproefbedrijven } \\
\text { in } \% \text { van de totale } \\
\text { doelpopulatie }\end{array}$ & $\begin{array}{l}\text { Steekproef- } \\
\text { oppervlakte in \% van } \\
\text { de totale oppervlakte }\end{array}$ \\
\hline \multicolumn{4}{|l|}{ Oppervlakte } \\
\hline 5 tot 25 ha & 39 & 4,3 & 4,7 \\
\hline 25 tot 50 ha & 24 & 11,0 & 12,3 \\
\hline 50 tot 100 ha & 26 & 19,8 & 20,5 \\
\hline 100 tot 250 ha & 27 & 38,6 & 41,2 \\
\hline 250 ha en meer & 21 & 52,5 & 57,9 \\
\hline \multicolumn{4}{|l|}{ Regio } \\
\hline Noordoost & 53 & 8,3 & 32,1 \\
\hline Centrum & 56 & 15,1 & 39,2 \\
\hline Zuid & 28 & 7,8 & 31,2 \\
\hline Totaal & 137 & 10,0 & 34,1 \\
\hline
\end{tabular}

Bron: Bedrijveninformatienet, Wageningen Economic Research.

Over 2019 zijn de gegevens verzameld van 137 deelnemers ('steekproefbedrijven'). Deze vormen $10 \%$ van het aantal bedrijven in de doelpopulatie en $34 \%$ van de totale bosoppervlakte van de doelpopulatie (tabel B1.2).

\section{B1.4 Opbouw en interpretatie van het bedrijfsresultaat}

Van de bedrijven in de steekproef worden zogenaamde deeladministraties bijgehouden. Dat wil zeggen dat alleen opbrengsten en kosten die te maken hebben met het bosbedrijf worden geregistreerd.

De bedrijfsuitkomsten in de particuliere bosbouw worden beschreven aan de hand van bedrijfsresultaat, rentabiliteit, inkomen, opbrengsten en kosten uit het bosbedrijf:

- Het bedrijfsresultaat is het saldo van opbrengsten en kosten, en geeft aan of de bosbouwactiviteiten bedrijfseconomisch rendabel zijn, met andere woorden, in hoeverre de gangbare beloningsaanspraken van de productiefactoren worden gehonoreerd. Voor de door de ondernemer en zijn gezin ingebrachte productiefactoren worden (normatief) kosten in rekening gebracht, maar over het in grond en houtopstand geïnvesteerde vermogen worden geen rentekosten berekend.

- De rentabiliteit wordt uitgedrukt in de verhouding tussen opbrengsten en kosten (in procenten). Als deze verhouding onder de $100 \%$ ligt, blijft het resultaat achter bij de gangbare beloningsaanspraken van de productiefactoren. Hierbij wordt aangetekend dat de rentekosten in grond/opstanden niet zijn meegenomen. 
- Het inkomen uit het bosbedrijf wordt berekend door het bedrijfsresultaat te vermeerderen met de berekende arbeidskosten van de eigenaar en de overige berekende Ionen. Het inkomen uit het bosbedrijf geeft weer wat de beloning van de eigenaar is voor risico, management en arbeid.

- De opbrengsten bestaan uit de opbrengsten van hout, jacht en recreatie en dergelijke, en subsidies. Verhuurt een eigenaar de jacht niet, maar jaagt hij zelf, dan worden daar (normatief) opbrengsten voor in rekening gebracht.

- De kosten bestaan uit arbeidskosten, rente, afschrijving en overige kosten (zoals heffingen, verzekeringen, plantsoen en zaad, brandstoffen enzovoort). De kosten van de door de ondernemer en zijn gezin ingebrachte productiefactoren worden normatief berekend. Over het in grond en houtopstanden geïnvesteerde vermogen worden echter geen rentekosten berekend. De kosten zijn onder meer ingedeeld naar kostensoorten en kostenplaatsen (activiteiten/maatregelen), zoals bosverjonging, bosonderhoud en houtoogst.

De gepresenteerde cijfers zijn gewogen schattingen op basis van de verhouding tussen steekproef en populatie.

Voor vergelijkingen in de tijd zijn de nominale bedragen in enkele gevallen (hoofdstuk 4) omgerekend naar reële bedragen met behulp van de prijsmutatie van het bruto binnenlands product. Als dat gebeurd is, wordt het vermeld. In alle andere gevallen zijn de bedragen nominaal.

\section{B1.5 Opbrengsten}

\section{Houtopbrengsten}

De houtopbrengsten bestaan uit het tot en met 31 december van het betreffende jaar op stam dan wel geveld verkochte hout. Het komt weinig voor dat er op 31 december niet-verkochte voorraden geveld hout op het bosbedrijf aanwezig zijn. Daarom zijn eventuele voorraadcijfers niet in de exploitatierekening van het betreffende boekjaar verwerkt. Voorschotten en afrekeningen worden verwerkt in het jaar van ontvangst.

\section{Overige houtopbrengsten}

De overige houtopbrengsten bestaan uit verkoop van afvalhout, brandhout, houtchips en boerengeriefhout.

\section{Subsidies en bijdragen}

Voor de ondersteuning van het bosbeheer zijn in de loop van de tijd verschillende subsidieprogramma's ontwikkeld. In het verleden konden boseigenaren onder meer in aanmerking komen voor een vaste hectarevergoeding van de overheid op basis van een door het Staatsbosbeheer goedgekeurd beheersplan. Met ingang van 1 september 1988 werd de Regeling Bosbijdragen samen met een aantal andere subsidieregelingen vervangen door de Regeling Bijdragen Bos- en Landschapsbouw. Hierin was een vaste bijdrage voor het onderdeel 'duurzame instandhouding' van bos opgenomen. Met ingang van 1994 is deze regeling (gedeeltelijk) vervangen door de Regeling Functiebeloning Bos en Natuurterreinen.

\section{Programma Beheer: Subsidieregeling natuurbeheer 2000}

Per 1 januari 2000 werd voor een groot aantal bedrijven de Regeling Functiebeloning vervangen door de regelingen van het Programma Beheer. Deze regeling beoogde particulieren bij het natuurbeheer te betrekken. Er werden subsidies verstrekt op basis van zogenoemde doelpakketten. Voor particuliere boseigenaren waren de belangrijkste pakketten: (1) bos, (2) bos met verhoogde natuurwaarde en (3) natuurbos. In 2012 golden de volgende vergoedingen (provinciale regeling), ingedeeld naar soort subsidie:

- Beheersubsidie, voor instandhouding van basispakket bos (55,37 euro per ha), pluspakket bos (74,99 euro per ha) en natuurbos (83,06 euro per ha). Het terrein waarvoor subsidie is aangevraagd moet ten minste 358 dagen kosteloos worden opengesteld. De aparte toeslag voor openstelling $(10,19$ euro per ha in 2003) is vervallen. Ontheffing van de verplichting tot openstelling is in 
bijzondere omstandigheden mogelijk, bijvoorbeeld op grond van zwaarwegende natuurwetenschappelijke belangen.

- Inrichtingssubsidie, voor het eenmalig creëren van een betere uitgangspositie voor natuurontwikkeling.

- Recreatiesubsidie, voor het in stand houden van recreatievoorzieningen. Tegelijk met het vervallen van de openstellingstoeslag is het onderscheid tussen het 'lage' recreatiepakket (14,27 euro per ha in 2003) en 'hoge' recreatiepakket (24,46 euro per ha in 2003) verdwenen. Er was sinds 2004 één recreatiepakket voor heel het land, met een vergoeding van 33,34 euro per ha in 2012.

\section{Subsidieverordening Natuur- en Landschapsbeheer (SVNL)}

Vanaf 2012 vindt een (geleidelijke) overgang plaats van subsidiëring via het Programma Beheer naar subsidiëring via het Subsidiestelsel Natuur- en Landschap (SNL), onder de verantwoordelijkheid van de provincies. De 'Subsidieverordening Natuur- en Landschapsbeheer' (SVNL) binnen het SNL is gericht op het beheer van natuur en landschap. De modelverordening en -regeling worden jaarlijks door de gezamenlijke provincies bijgesteld en door de afzonderlijke provincies vastgesteld. Met behulp van de Index Natuur en Landschap worden de typen natuur, agrarische natuur en landschap in Nederland beschreven. De index is een gemeenschappelijke, landelijk uniforme 'natuurtaal'. In 2018 is de standaardkostprijs voor bos met productiefunctie aangepast. In 2019 bedraagt het tarief voor 'droog bos met productiefunctie' 26 euro per ha (24 euro in 2018) en voor 'vochtig bos met productiefunctie' 45 euro per ha (44 euro in 2018).

\section{Subsidieregeling Kwaliteitsimpuls Natuur en Landschap (SKNL)}

Deze subsidieregeling binnen het Subsidiestelsel Natuur- en Landschap (SNL) is gericht op investeringen in natuur en landschap (omvorming, inrichting en kwaliteitsontwikkeling). Op basis van de SKNL kunnen Gedeputeerde Staten subsidie verstrekken voor eenmalige investeringen in bos- en natuurterreinen, met als doel de verhoging van de natuurkwaliteit van het bestaande natuurbeheertype of landschapsbeheertype, en de omzetting van een natuurterrein met een bepaald natuurbeheertype naar een ander gewenst natuurbeheertype. De hoogte van de subsidie bedraagt $95 \%$ van de goedgekeurde kosten. De provincies kunnen een maximumbedrag per hectare vaststellen. Een voorbeeld van kwaliteitsverbetering is het plaggen van een grotere oppervlakte heide om vergrassing tegen te gaan. De regeling voor kwaliteitsimpuls is in 2010 voor het eerst opengesteld.

\section{Jachthuur}

Daar elk bos een potentieel jachtgebied is, zijn de opbrengsten uit jachtverhuur in de exploitatierekening opgenomen. Indien de bossen niet voor de jacht zijn verhuurd, is ten behoeve van de wildregulatie het jachtgenot voor de eigenaar normatief als opbrengst opgenomen. Deze gegevens zijn vanaf 1981 bekend. Om een juiste vergelijking met de voorgaande jaren mogelijk te maken, is deze opbrengst voor de voorliggende jaren normatief teruggerekend.

\section{Kerstbomen en -groen}

De verkopen van kerstbomen en -groen. Het betreft opbrengsten van kerstbomenuitdunningen, evenals de opbrengsten van een speciaal aangelegde kerstbomenkwekerij.

\section{Recreatie}

De recreatieopbrengsten bestaan onder meer uit de opbrengsten van een boscamping en natuur- en groepskampeerterreinen in het bos, excursies, entree-, vervoer- en parkeergelden, fietsverhuur, wandel-/fiets-/ruiterkaarten en visvergunningen. De opbrengsten van de werkzaamheden door vrijwilligers (bijvoorbeeld ANWB-landgoedkampeerders, scouts) worden als recreatieopbrengsten meegenomen en gelijk verondersteld aan de berekende kosten. Bij de berekening van het bedrijfsresultaat vallen de betreffende opbrengsten en kosten tegen elkaar weg.

\section{Overige bedrijfsopbrengsten}

De overige bedrijfsopbrengsten bestaan onder meer uit de verkoop van uitgangsmateriaal zoals plantsoen en zaden uit het bos, opstalrecht (ten behoeve van leidingen, zendmasten enzovoort), verhuur van bos aan derden (zoals hondenclubs, scouting, voor militaire oefeningen, rally's, 
crosscountry's enzovoort). Verder is hierin opgenomen de vergoeding voor schade aan het bos, zoals door brand, storm of ijzel- en sneeuwdruk.

\section{Incidentele nevenopbrengsten}

Ontvangen vergoedingen voor meestal eenmalig gebruik van (gedeeltelijke) bosterreinen, bijvoorbeeld voor slibberging. Hieronder vallen ook de opbrengsten van overgenomen herplantplichten, plantrechtsafstand van laanbomen enzovoort.

\section{B1.6 Kosten}

\section{Loon eigen personeel}

Salaris, vakantie- en eindejaarsuitkering, sociale en overige toeslagen voor personeel met een vast arbeidscontract, ten behoeve van het terreinbeheer, en salariskosten van personeel zonder vast arbeidscontract (zoals uitzendkrachten, gedetacheerden, adviseurs), ten behoeve van het terreinbeheer.

\section{Berekende lonen}

Voor niet-betaalde bosarbeid worden loonkosten op normatieve wijze berekend. Deze arbeid kan zijn verricht door de eigenaar of diens familieleden, ANWB-landgoedkampeerders, scholieren en scouts, enzovoort. Voor hun arbeid - waarvoor ze geen loon ontvangen - worden in de bedrijfseconomische boekhouding kosten opgevoerd (uren maal een normatieve uurvergoeding, ruim 10 euro in 2019). Hiermee worden de inspanningen voor het beheer zichtbaar gemaakt.

Voor de eigenaar of diens familieleden is in 2019 een bedrag van 31,62 euro per uur opgenomen. Dit is afgeleid van het gemiddelde uurloon van een bosarbeider volgens de cao-bosbouw (inclusief de wettelijk verplichte sociale lasten). Voor de managementactiviteiten van de eigenaar (beheer, leiding en toezicht) wordt een hoger uurtarief aangehouden (38,56 euro). Voor de overige categorieën (vrijwilligers) is met 10,16 euro per uur gerekend, te weten genoemd cao-loon van de bosarbeider vermenigvuldigd met een reductiefactor voor geringere vakbekwaamheid en productiviteit.

\section{Werk door derden}

De kosten voor het terreinbeheer die door derden in rekening worden gebracht, zoals de bosgroep, rentmeester, ingenieursbureau, loonwerker en een collega-natuurbeheerder. Niet opgenomen in deze post zijn de oogstkosten voor op stam verkocht hout, zowel uitdunning als eindkap. De kosten daarvan zijn in een lagere prijs per verkochte kubieke meter hout tot uiting gebracht. Onder werk door derden vallen ook de kosten van arbeid in het kader van de diverse werkgelegenheidsregelingen. De betreffende overheidsbijdrage is opgenomen onder de post 'Subsidies en bijdragen'.

\section{Machines, werktuigen en auto's}

De waarde van de machines, werktuigen en auto's die worden gebruikt voor het bosbeheer worden in samenspraak met de deelnemer getaxeerd. De afschrijvingen en rentekosten worden berekend conform de methodiek van Wageningen Economic Research voor land- en tuinbouw. Er is gerekend met een standaardrentepercentage over het gemiddeld geïnvesteerd vermogen (het gemiddelde van de waarde op de begin- en eindbalans) in machines, werktuigen en auto's. De overige kosten van machines, werktuigen en auto's bestaan onder meer uit kosten voor onderhoud, reparatie, brandstof en verzekeringen, evenals de vergoeding (28 eurocent per kilometer) voor de door de eigenaar met zijn privéauto verreden kilometers ten behoeve van het bosbedrijf.

\section{Grond- en hulpstoffen}

Kosten voor aangekocht zaaizaad, plantsoen, meststoffen en bestrijdingsmiddelen. De overige materialen bestaan voornamelijk uit materialen ten behoeve van wegverharding, afrasteringen, duikers enzovoort.

\section{Heffingen en verzekeringen}

Op de bossen drukkende waterschapslasten en heffingen opgelegd door het Bosschap. Met het einde van de publiekrechtelijke bedrijfsorganisatie zijn de heffingen van het Bosschap na 2014 vervallen. 
Indien de bossen geheel of gedeeltelijk zijn verzekerd tegen bosbrand dan wel stormschade, behoort de verschuldigde premie tot deze kostencategorie.

\section{Overige bedrijfskosten}

De overige kosten omvatten kosten van gebouwen (inclusief kantoor) in gebruik voor het bosbeheer, zoals rente en afschrijving, verzekeringen en onderhoud, kantoormateriaal, telecommunicatie en energie/water. Ook worden in deze post meegenomen: de betaalde contributies, abonnementen op vakbladen, betaalde pensioenen aan oud-bosarbeiders of hun partners, representatiekosten en de premie voor de bedrijfs-WA-verzekering.

\section{B1.7 Kostenplaatsen}

De diverse kostensoorten kunnen worden toegerekend naar kostenplaatsen, ook wel aangeduid met maatregelen of activiteiten. Deze zijn ingedeeld naar een aantal hoofdgroepen.

\section{Algemeen bosbeheer}

De algemene kosten hebben betrekking op beheer, leiding en toezicht, heffingen en verzekeringen, en overige algemene kosten (niet toe te rekenen aan activiteiten).

Onder beheer, leiding en toezicht vallen onder andere het plannen, begroten en opstellen van beheeren werkplannen, het uitbesteden en organiseren van werkzaamheden, het aanvragen van subsidies, de verkoop van hout, onderzoek en monitoring, en het toezicht op de uitvoering van werkzaamheden en de dagelijkse gang van zaken in het bos, inclusief toezicht op recreanten. De kosten voor deze activiteiten bestaan uit (berekende) Ionen en betaalde kosten voor bijvoorbeeld een rentmeester, bosgroep en ingenieursbureau.

\section{Bosverjonging}

Kosten voor bodembewerking, plantwerkzaamheden voor (her)bebossing en inboetwerkzaamheden.

\section{Bosonderhoud}

De activiteiten jeugdverzorging (vrijstellen en zuiveren), opkronen, prunusbestrijding (of andere ongewenste houtopslag), onrendabele dunning (stamtaalreductie zonder ontvangsten) en het aanwijzen van toekomstbomen.

\section{Infrastructuur}

Kosten voor werkzaamheden en materialen ten behoeve van wegen, paden, waterlopen, hekken, rasters en recreatieve voorzieningen.

\section{Houtoogst (vellingen)}

Deze kosten bestaan uit arbeidskosten, werk door derden en werktuigkosten (voor zover gemaakt bij zelf uitgevoerde dunningen en kaalslagen). Met ingang van 1997 is de post 'Blessen en meten uit beheer en leiding' geplaatst onder de post 'Houtoogst'. Het betreft de kosten voor het blessen van de te vellen bomen bij een dunning, evenals het meten van het gevelde hout (zowel dunning als eindkap). Bijna altijd vindt dit plaats bij zowel op stam als geveld verkocht hout. 


\section{Bijlage 2 Tabellen}

\section{B2.1 Bedrijfsresultaten per hectare}

Tabel B2.1 Bedrijfsresultaat (euro per ha bos) particuliere bosbedrijven, 2015-2019

\begin{tabular}{|c|c|c|c|c|c|c|}
\hline Kosten & 2015 & 2016 & 2017 & 2018 & 2019 & Gemiddeld \\
\hline \multicolumn{7}{|l|}{ Arbeid (uitvoerend) } \\
\hline loon eigen personeel & 38 & 38 & 44 & 46 & 38 & 41 \\
\hline berekend loon & 35 & 38 & 40 & 47 & 47 & 41 \\
\hline Totaal & 73 & 76 & 84 & 93 & 85 & 82 \\
\hline \multicolumn{7}{|l|}{ Beheer, leiding en toezicht } \\
\hline beheer en leiding & 56 & 56 & 61 & 62 & 71 & 61 \\
\hline Toezicht & 29 & 27 & 31 & 35 & 33 & 31 \\
\hline blessen en meten (arbeid) & 1 & 1 & 1 & 1 & 1 & 1 \\
\hline blessen en meten (loonwerk) & 5 & 6 & 5 & 3 & 5 & 5 \\
\hline Totaal & 91 & 90 & 98 & 102 & 110 & 98 \\
\hline \multicolumn{7}{|l|}{ Werk door derden } \\
\hline (her)bebossing & 4 & 8 & 12 & 5 & 11 & 8 \\
\hline Bosonderhoud & 27 & 26 & 28 & 28 & 29 & 28 \\
\hline Houtoogst & 9 & 13 & 14 & 21 & 16 & 15 \\
\hline Infrastructuur & 14 & 9 & 13 & 14 & 14 & 13 \\
\hline Totaal & 53 & 55 & 66 & 68 & 70 & 62 \\
\hline Werktuigen & 24 & 24 & 25 & 24 & 24 & 24 \\
\hline Grond- en hulpstoffen & 7 & 12 & 11 & 6 & 11 & 9 \\
\hline \multicolumn{7}{|l|}{ Grond en houtopstand } \\
\hline waterschapslasten & 4 & 4 & 4 & 4 & 4 & 4 \\
\hline heffing Bosschap & 0 & 0 & 0 & 0 & 0 & 0 \\
\hline Bosbrandverzekering & 3 & 4 & 4 & 3 & 3 & 3 \\
\hline Totaal & 8 & 8 & 8 & 8 & 8 & 8 \\
\hline Overige bedrijfskosten & 23 & 24 & 23 & 24 & 23 & 23 \\
\hline Totaal exploitatiekosten & 279 & 289 & 315 & 325 & 331 & 308 \\
\hline Positief bedrijfsresultaat & 14 & & & & & 3 \\
\hline Totaal & 293 & 289 & 315 & 325 & 331 & 311 \\
\hline
\end{tabular}

Tabel B2.1 (vervolg) Bedrijfsresultaat (euro per ha bos) particuliere bosbedrijven, 2015-2019

\begin{tabular}{|c|c|c|c|c|c|c|}
\hline Opbrengsten & 2015 & 2016 & 2017 & 2018 & 2019 & Gemiddeld \\
\hline \multicolumn{7}{|l|}{ Houtopbrengsten } \\
\hline op stam verkocht & 120 & 101 & 90 & 106 & 77 & 99 \\
\hline geveld verkocht & 11 & 14 & 14 & 8 & 17 & 13 \\
\hline overige houtopbrengsten & 6 & 9 & 9 & 9 & 6 & 8 \\
\hline totaal houtopbrengsten & 137 & 123 & 112 & 123 & 100 & 119 \\
\hline \multicolumn{7}{|l|}{ Overig bedrijfsopbrengsten } \\
\hline Jachthuur & 15 & 15 & 15 & 15 & 14 & 15 \\
\hline kerstbomen en -groen & 4 & 7 & 6 & 0 & 0 & 3 \\
\hline Recreatie & 32 & 32 & 30 & 35 & 34 & 33 \\
\hline Overige & 23 & 15 & 14 & 19 & 18 & 18 \\
\hline Totaal & 74 & 68 & 65 & 68 & 66 & 68 \\
\hline Incidentele opbrengsten & 0 & 1 & 1 & 3 & 1 & 1 \\
\hline \multicolumn{7}{|l|}{ Subsidies en bijdragen } \\
\hline Beheersubsidie & 72 & 73 & 73 & 78 & 79 & 75 \\
\hline Overige & 9 & 15 & 22 & 13 & 17 & 15 \\
\hline Totaal & 81 & 88 & 94 & 91 & 97 & 90 \\
\hline Totaal bedrijfsopbrengsten & 293 & 281 & 271 & 285 & 264 & 279 \\
\hline Negatief bedrijfsresultaat & & 8 & 44 & 40 & 67 & 32 \\
\hline Totaal & 293 & 289 & 315 & 325 & 331 & 311 \\
\hline
\end{tabular}


Tabel B2.2 Bedrijfsresultaat (euro per ha bos) particuliere bosbedrijven naar bosareaal in ha, 2019

\begin{tabular}{|c|c|c|c|c|c|c|c|}
\hline Kosten & $5-25$ & $25-50$ & $50-100$ & $100-250$ & $\geq 250$ & $\begin{array}{r}\text { Totaal } \\
2019\end{array}$ & $\begin{array}{r}\text { Totaal } \\
2018\end{array}$ \\
\hline \multicolumn{8}{|l|}{ Arbeid } \\
\hline loon eigen personeel & 85 & 10 & 34 & 84 & 91 & 70 & 75 \\
\hline diverse berekende Ionen & 255 & 148 & 39 & 29 & 5 & 77 & 80 \\
\hline Totaal & 339 & 157 & 73 & 113 & 96 & 147 & 155 \\
\hline \multicolumn{8}{|l|}{ Werk door derden } \\
\hline Loonwerker & 46 & 59 & 88 & 64 & 39 & 54 & 58 \\
\hline rentmeester en overig & 31 & 97 & 118 & 64 & 47 & 63 & 50 \\
\hline Totaal & 77 & 155 & 207 & 128 & 86 & 118 & 108 \\
\hline \multicolumn{8}{|l|}{ Werktuigen } \\
\hline rente en afschrijving & 14 & 2 & 6 & 7 & 5 & 7 & 7 \\
\hline overige werktuigkosten & 31 & 12 & 14 & 14 & 15 & 17 & 17 \\
\hline Totaal & 45 & 14 & 19 & 21 & 20 & 24 & 24 \\
\hline \multicolumn{8}{|l|}{ Grond- en hulpstoffen } \\
\hline plantsoen en zaad & 11 & 4 & 8 & 7 & 5 & 7 & 3 \\
\hline mest-/bestrijdingsmiddelen & 0 & 0 & 0 & 0 & 0 & 0 & 0 \\
\hline overige grond-/hulpstoffen & 3 & 3 & 3 & 6 & 6 & 4 & 2 \\
\hline Totaal & 14 & 7 & 10 & 13 & 11 & 11 & 6 \\
\hline \multicolumn{8}{|l|}{ Bosinstandhouding } \\
\hline gebouwen en infrastructuur & 18 & 0 & 6 & 1 & 0 & 4 & 5 \\
\hline grond/waterschapslasten & 4 & 7 & 4 & 5 & 4 & 4 & 4 \\
\hline heffing bosschap & 0 & 0 & 0 & 0 & 0 & 0 & 0 \\
\hline Bosbrandverzekering & 4 & 5 & 4 & 4 & 2 & 3 & 3 \\
\hline Totaal & 26 & 12 & 14 & 11 & 6 & 13 & 13 \\
\hline Overige bedrijfskosten & 24 & 24 & 15 & 18 & 15 & 18 & 19 \\
\hline Totaal exploitatiekosten & 526 & 370 & 338 & 304 & 234 & 331 & 325 \\
\hline Positief bedrijfsresultaat & & & & & 15 & & \\
\hline Totaal & 526 & 370 & 338 & 304 & 249 & 331 & 325 \\
\hline
\end{tabular}

Tabel B2.2 (vervolg) Bedrijfsresultaat (euro per ha bos) particuliere bosbedrijven naar bosareaal in ha, 2019

\begin{tabular}{|c|c|c|c|c|c|c|c|}
\hline Opbrengsten & $5-25$ & $25-50$ & $50-100$ & $100-250$ & $\geq 250$ & $\begin{array}{r}\text { Totaal } \\
2019\end{array}$ & $\begin{array}{r}\text { Totaal } \\
2018\end{array}$ \\
\hline \multicolumn{8}{|l|}{ Houtopbrengsten } \\
\hline op stam & 20 & 37 & 96 & 90 & 106 & 77 & 106 \\
\hline Geveld & 29 & 2 & 74 & 1 & 2 & 17 & 8 \\
\hline overige houtopbrengsten & 10 & 3 & 5 & 5 & 6 & 6 & 9 \\
\hline Totaal & 59 & 41 & 174 & 95 & 114 & 100 & 123 \\
\hline \multicolumn{8}{|l|}{ Overige bedrijfsopbrengsten } \\
\hline Jachthuur & 10 & 8 & 12 & 16 & 17 & 14 & 15 \\
\hline kerstbomen en -groen & 0 & 0 & 0 & 0 & 0 & 0 & 0 \\
\hline recreatie, boscamping & 47 & 0 & 0 & 0 & 4 & 10 & 10 \\
\hline recreatie, overig & 74 & 8 & 18 & 30 & 6 & 24 & 25 \\
\hline Overige & 42 & 17 & 5 & 8 & 17 & 18 & 19 \\
\hline Totaal & 172 & 33 & 35 & 54 & 45 & 66 & 68 \\
\hline Incidentele opbrengsten & 0 & 0 & 0 & 3 & 0 & 1 & 3 \\
\hline \multicolumn{8}{|l|}{ Subsidies en bijdragen } \\
\hline Beheersubsidie & 69 & 73 & 69 & 88 & 86 & 79 & 78 \\
\hline overige subsidies & 18 & 42 & 5 & 36 & 5 & 17 & 13 \\
\hline Totaal & 87 & 115 & 74 & 125 & 91 & 97 & 91 \\
\hline Totaal bedrijfsopbrengsten & 319 & 189 & 283 & 277 & 249 & 264 & 285 \\
\hline Negatief bedrijfsresultaat & 207 & 181 & 55 & 27 & & 67 & 40 \\
\hline Totaal & 526 & 370 & 338 & 304 & 249 & 331 & 325 \\
\hline
\end{tabular}


Tabel B2.3 Bedrijfsresultaten (euro per ha bos) alle bedrijven naar regio, 2019

\begin{tabular}{|c|c|c|c|c|c|}
\hline Kosten & Noordoost & Centrum & Zuid & Totaal 2019 & Totaal 2018 \\
\hline \multicolumn{6}{|l|}{ Arbeid } \\
\hline loon eigen personeel & 61 & 115 & 31 & 70 & 75 \\
\hline diverse berekende Ionen & 92 & 104 & 23 & 77 & 80 \\
\hline Totaal & 153 & 219 & 54 & 147 & 155 \\
\hline \multicolumn{6}{|l|}{ Werk door derden } \\
\hline Loonwerker & 46 & 81 & 36 & 54 & 58 \\
\hline rentmeester en overig & 81 & 57 & 43 & 63 & 50 \\
\hline Totaal & 127 & 137 & 79 & 118 & 108 \\
\hline \multicolumn{6}{|l|}{ Werktuigen } \\
\hline rente en afschrijving & 9 & 8 & 1 & 7 & 7 \\
\hline overige werktuigkosten & 15 & 29 & 7 & 17 & 17 \\
\hline Totaal & 24 & 37 & 9 & 24 & 24 \\
\hline \multicolumn{6}{|l|}{ Grond- en hulpstoffen } \\
\hline plantsoen en zaad & 11 & 5 & 3 & 7 & 3 \\
\hline mest- en bestrijdingsmiddelen & 0 & 0 & 0 & 0 & 0 \\
\hline overige grond- en hulpstoffen & 3 & 10 & 2 & 4 & 2 \\
\hline Totaal & 14 & 14 & 4 & 11 & 6 \\
\hline \multicolumn{6}{|l|}{ Bosinstandhouding } \\
\hline gebouwen en infrastructuur & 2 & 11 & 0 & 4 & 5 \\
\hline grond-/waterschapslasten & 5 & 5 & 3 & 4 & 4 \\
\hline heffing bosschap & 0 & 0 & 0 & 0 & 0 \\
\hline Bosbrandverzekering & 3 & 4 & 4 & 3 & 3 \\
\hline Totaal & 10 & 21 & 7 & 13 & 13 \\
\hline Overige bedrijfskosten & 17 & 25 & 11 & 18 & 19 \\
\hline Totaal exploitatiekosten & 345 & 454 & 165 & 331 & 325 \\
\hline Positief bedrijfsresultaat & & & 10 & & \\
\hline Totaal & 345 & 454 & 175 & 331 & 325 \\
\hline
\end{tabular}

Tabel B2.3 (vervolg) Bedrijfsresultaten (euro per ha bos) alle bedrijven naar regio, 2019

\begin{tabular}{|c|c|c|c|c|c|}
\hline Opbrengsten & Noordoost & Centrum & Zuid & Totaal 2019 & Totaal 2018 \\
\hline \multicolumn{6}{|l|}{ Houtopbrengsten } \\
\hline op stam & 65 & 108 & 60 & 77 & 106 \\
\hline overige houtopbrengsten & 7 & 9 & 1 & 6 & 9 \\
\hline Totaal & 109 & 119 & 63 & 100 & 123 \\
\hline kerstbomen en -groen & 0 & 0 & 0 & 0 & 0 \\
\hline recreatie, boscamping & 4 & 27 & 0 & 10 & 10 \\
\hline recreatie, overige opbrengst & 8 & 51 & 18 & 24 & 25 \\
\hline Overige & 12 & 37 & 7 & 18 & 19 \\
\hline \multicolumn{6}{|l|}{ Subsidies en bijdragen } \\
\hline Beheersubsidie & 94 & 67 & 70 & 79 & 78 \\
\hline overige subsidies & 30 & 15 & 1 & 17 & 13 \\
\hline Totaal & 124 & 81 & 71 & 97 & 91 \\
\hline Totaal bedrijfsopbrengsten & 266 & 336 & 174 & 264 & 285 \\
\hline Negatief bedrijfsresultaat & 79 & 118 & & 67 & 40 \\
\hline Totaal & 345 & 454 & 174 & 331 & 325 \\
\hline
\end{tabular}


Tabel B2.4 Kosten arbeid en loonwerk (euro per ha bos) particuliere bosbedrijven naar omvang bosareaal in ha, 2019

\begin{tabular}{|c|c|c|c|c|c|c|c|}
\hline Kosten & $5-25$ & $25-50$ & $50-100$ & $100-250$ & $\geq 250$ & $\begin{array}{r}\text { Totaal } \\
2019\end{array}$ & $\begin{array}{r}\text { Totaal } \\
2018\end{array}$ \\
\hline \multicolumn{8}{|c|}{ Arbeid, betaald loon eigen personeel } \\
\hline beheer en leiding & 6 & 1 & 2 & 14 & 30 & 15 & 14 \\
\hline Toezicht & 4 & 1 & 11 & 29 & 24 & 16 & 15 \\
\hline Bosverjonging & 2 & 0 & 0 & 4 & 2 & 2 & 2 \\
\hline Bosverzorging & 43 & 7 & 19 & 26 & 28 & 26 & 31 \\
\hline Houtoogst & 0 & 0 & 1 & 5 & 2 & 2 & 3 \\
\hline Infrastructuur & 29 & 1 & 1 & 6 & 5 & 8 & 10 \\
\hline Totaal & 85 & 10 & 34 & 84 & 91 & 70 & 75 \\
\hline \multicolumn{8}{|l|}{ Arbeid, berekend loon } \\
\hline beheer en leiding & 45 & 42 & 14 & 11 & 1 & 18 & 18 \\
\hline Toezicht & 40 & 21 & 7 & 5 & 1 & 12 & 14 \\
\hline Bosverjonging & 6 & 31 & 1 & 0 & 1 & 6 & 1 \\
\hline Bosverzorging & 124 & 25 & 15 & 11 & 1 & 30 & 32 \\
\hline Houtoogst & 14 & 23 & 2 & 1 & 0 & 6 & 9 \\
\hline Infrastructuur & 24 & 6 & 1 & 0 & 0 & 5 & 6 \\
\hline Totaal & 255 & 148 & 39 & 29 & 5 & 77 & 80 \\
\hline \multicolumn{8}{|l|}{ Loonwerk } \\
\hline beheer en leiding & 17 & 61 & 59 & 49 & 28 & 38 & 31 \\
\hline Toezicht & 13 & 5 & 5 & 2 & 0 & 4 & 6 \\
\hline Bosverjonging & 5 & 15 & 28 & 9 & 7 & 11 & 5 \\
\hline Bosverzorging & 32 & 42 & 32 & 28 & 23 & 29 & 28 \\
\hline Houtoogst & 4 & 10 & 63 & 17 & 20 & 21 & 25 \\
\hline Infrastructuur & 5 & 23 & 18 & 22 & 9 & 14 & 14 \\
\hline Totaal & 77 & 155 & 207 & 128 & 86 & 118 & 108 \\
\hline Overige kosten & 110 & 57 & 58 & 63 & 53 & 66 & 62 \\
\hline Totaal & 526 & 370 & 338 & 304 & 234 & 331 & 325 \\
\hline
\end{tabular}

Tabel B2.5 Kosten arbeid en loonwerk (euro per ha bos) particuliere bosbedrijven naar regio, 2019

\begin{tabular}{|c|c|c|c|c|c|}
\hline Kosten & Noordoost & Centrum & Zuid & Totaal 2019 & Totaal 2018 \\
\hline \multicolumn{6}{|c|}{ Arbeid, betaald loon eigen personeel } \\
\hline beheer en leiding & 16 & 17 & 12 & 15 & 14 \\
\hline Toezicht & 18 & 16 & 15 & 16 & 15 \\
\hline Bosverjonging & 2 & 3 & 0 & 2 & 2 \\
\hline Bosverzorging & 18 & 59 & 2 & 26 & 31 \\
\hline Houtoogst & 3 & 1 & 1 & 2 & 3 \\
\hline Infrastructuur & 5 & 20 & 1 & 8 & 10 \\
\hline Totaal & 61 & 115 & 31 & 70 & 75 \\
\hline \multicolumn{6}{|l|}{ Arbeid, berekend loon } \\
\hline beheer en leiding & 21 & 23 & 7 & 18 & 18 \\
\hline Toezicht & 19 & 6 & 9 & 12 & 14 \\
\hline Bosverjonging & 12 & 1 & 1 & 6 & 1 \\
\hline Bosverzorging & 28 & 56 & 3 & 30 & 32 \\
\hline Houtoogst & 10 & 5 & 0 & 6 & 9 \\
\hline Infrastructuur & 2 & 13 & 2 & 5 & 6 \\
\hline Totaal & 92 & 104 & 23 & 77 & 80 \\
\hline \multicolumn{6}{|l|}{ Loonwerk } \\
\hline beheer en leiding & 40 & 44 & 29 & 38 & 31 \\
\hline Toezicht & 1 & 4 & 10 & 4 & 6 \\
\hline Bosverjonging & 14 & 16 & 1 & 11 & 5 \\
\hline Bosverzorging & 26 & 40 & 22 & 29 & 28 \\
\hline Houtoogst & 36 & 13 & 8 & 21 & 25 \\
\hline Infrastructuur & 11 & 21 & 10 & 14 & 14 \\
\hline Totaal & 127 & 137 & 79 & 118 & 108 \\
\hline Overige kosten & 65 & 97 & 31 & 66 & 62 \\
\hline Totaal & 345 & 454 & 165 & 331 & 325 \\
\hline
\end{tabular}


Tabel B2.6 Bedrijfsresultaten (euro per ha bos) particuliere bosbedrijven groter dan 50 ha, 2015-2019

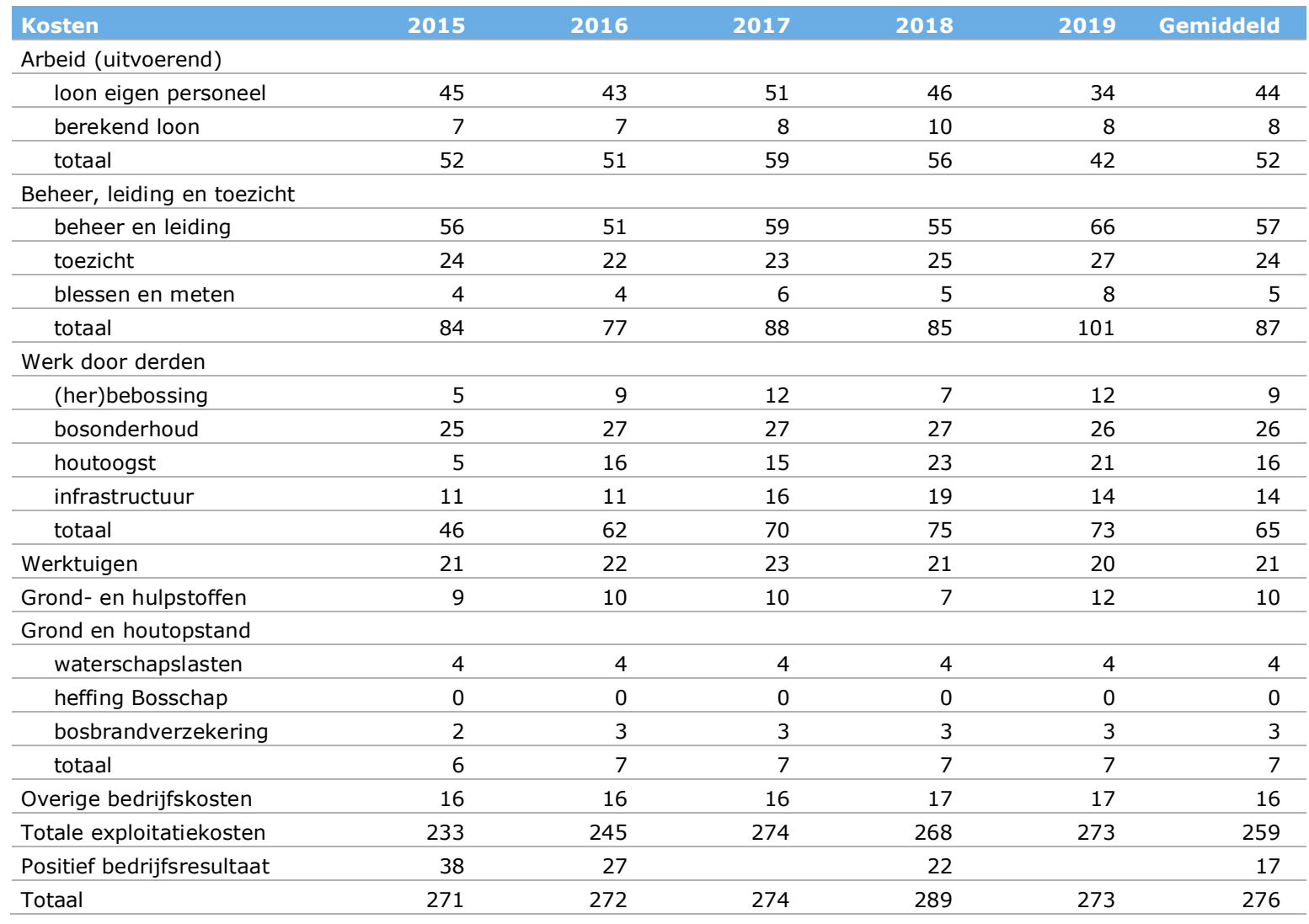

Tabel B2.6 (vervolg) Bedrijfsresultaten (euro per ha bos) particuliere bosbedrijven groter dan 50 ha, 2015-2019

\begin{tabular}{|c|c|c|c|c|c|c|}
\hline Opbrengsten & 2015 & 2016 & 2017 & 2018 & 2019 & Gemiddeld \\
\hline \multicolumn{7}{|l|}{ Houtopbrengsten } \\
\hline op stam verkocht & 114 & 116 & 111 & 130 & 100 & 114 \\
\hline overige houtopbrengsten & 7 & 8 & 9 & 9 & 5 & 8 \\
\hline totaal houtopbrengsten & 129 & 136 & 126 & 142 & 122 & 131 \\
\hline kerstbomen en -groen & 0 & 0 & 0 & 0 & 0 & 0 \\
\hline Recreatie & 15 & 15 & 13 & 17 & 17 & 15 \\
\hline Overige & 21 & 9 & 9 & 12 & 12 & 13 \\
\hline Totaal & 54 & 41 & 39 & 45 & 45 & 45 \\
\hline Overige & 10 & 16 & 28 & 14 & 13 & 16 \\
\hline Totaal & 87 & 93 & 105 & 99 & 96 & 96 \\
\hline Totale bedrijfsopbrengsten & 271 & 272 & 271 & 289 & 263 & 273 \\
\hline Negatief bedrijfsresultaat & & & 3 & & 10 & 3 \\
\hline Totaal & 271 & 272 & 274 & 289 & 273 & 276 \\
\hline
\end{tabular}


Tabel B2.7 Bedrijfsresultaten (euro per ha bos) particuliere bosbedrijven groter dan 50 ha naar regio, 2019

\begin{tabular}{|c|c|c|c|c|c|}
\hline Kosten & Noordoost & Centrum & Zuid & Totaal 2019 & Totaal 2018 \\
\hline \multicolumn{6}{|l|}{ Arbeid } \\
\hline Ioon eigen personeel & 90 & 84 & 46 & 77 & 84 \\
\hline Totaal & 113 & 96 & 63 & 95 & 103 \\
\hline \multicolumn{6}{|l|}{ Werk door derden } \\
\hline Totaal & 131 & 139 & 81 & 121 & 113 \\
\hline \multicolumn{6}{|l|}{ Werktuigen } \\
\hline rente en afschrijving & 9 & 4 & 2 & 6 & 6 \\
\hline overige werktuigkosten & 14 & 18 & 11 & 15 & 15 \\
\hline mest en bestrijdingsmiddel & 0 & 0 & 0 & 0 & 0 \\
\hline overige grond- en hulpstoffen & 2 & 12 & 1 & 5 & 2 \\
\hline Totaal & 12 & 18 & 2 & 12 & 7 \\
\hline \multicolumn{6}{|l|}{ Bosinstandhouding } \\
\hline gebouwen en infrastructuur & 3 & 1 & 0 & 2 & 1 \\
\hline grond-/waterschapslasten & 5 & 4 & 3 & 4 & 4 \\
\hline heffing bosschap & 0 & 0 & 0 & 0 & 0 \\
\hline Bosbrandverzekering & 3 & 2 & 4 & 3 & 3 \\
\hline Totaal & 11 & 8 & 7 & 9 & 8 \\
\hline Overige bedrijfskosten & 17 & 18 & 10 & 15 & 16 \\
\hline
\end{tabular}

Tabel B2.7 (vervolg) Bedrijfsresultaten (euro per ha bos) particuliere bosbedrijven groter dan 50 ha naar regio, 2019

\begin{tabular}{|c|c|c|c|c|c|}
\hline Opbrengsten & Noordoost & Centrum & Zuid & Totaal 2019 & Totaal 2018 \\
\hline \multicolumn{6}{|l|}{ Houtopbrengsten } \\
\hline op stam & 87 & 124 & 89 & 100 & 130 \\
\hline overige houtopbrengsten & 6 & 8 & 0 & 5 & 9 \\
\hline Totaal & 132 & 132 & 89 & 122 & 142 \\
\hline kerstbomen en -groen & 0 & 0 & 0 & 0 & 0 \\
\hline recreatie, boscamping & 6 & 0 & 0 & 2 & 2 \\
\hline recreatie, overige opbrengst & 9 & 11 & 28 & 14 & 15 \\
\hline Overige & 18 & 7 & 10 & 12 & 12 \\
\hline Beheersubsidie & 102 & 70 & 69 & 83 & 85 \\
\hline overige subsidies & 17 & 16 & 2 & 13 & 14 \\
\hline Totaal & 118 & 86 & 71 & 96 & 99 \\
\hline Totaal bedrijfsopbrengsten & 294 & 262 & 214 & 263 & 289 \\
\hline Negatief bedrijfsresultaat & 14 & 40 & & 10 & \\
\hline Totaal & 307 & 301 & 214 & 273 & 289 \\
\hline
\end{tabular}


Tabel B2.8 Kosten arbeid en loonwerk (euro per ha bos) particuliere bosbedrijven groter dan 50 ha naar regio, 2019

\begin{tabular}{|c|c|c|c|c|c|}
\hline Kosten & Noordoost & Centrum & Zuid & Totaal 2019 & Totaal 2018 \\
\hline \multicolumn{6}{|c|}{ Arbeid, betaald loon eigen personeel } \\
\hline beheer en leiding & 23 & 17 & 19 & 20 & 17 \\
\hline Toezicht & 26 & 17 & 22 & 22 & 20 \\
\hline Bosverjonging & 4 & 2 & 0 & 2 & 3 \\
\hline Bosverzorging & 26 & 43 & 2 & 26 & 32 \\
\hline Houtoogst & 4 & 2 & 2 & 3 & 5 \\
\hline Infrastructuur & 7 & 3 & 1 & 4 & 7 \\
\hline Totaal & 90 & 84 & 46 & 77 & 84 \\
\hline \multicolumn{6}{|l|}{ Arbeid, berekend loon } \\
\hline beheer en leiding & 8 & 3 & 7 & 6 & 6 \\
\hline Toezicht & 5 & 0 & 4 & 3 & 3 \\
\hline Bosverjonging & 0 & 0 & 2 & 1 & 0 \\
\hline Bosverzorging & 7 & 9 & 3 & 7 & 7 \\
\hline Houtoogst & 2 & 0 & 0 & 1 & 2 \\
\hline Infrastructuur & 0 & 0 & 1 & 0 & 1 \\
\hline Totaal & 23 & 12 & 17 & 18 & 19 \\
\hline \multicolumn{6}{|l|}{ Loonwerk } \\
\hline beheer en leiding & 42 & 46 & 28 & 40 & 32 \\
\hline Toezicht & 0 & 4 & 0 & 2 & 1 \\
\hline Bosverjonging & 11 & 22 & 1 & 12 & 7 \\
\hline Bosverzorging & 20 & 34 & 25 & 26 & 27 \\
\hline Houtoogst & 47 & 17 & 12 & 28 & 27 \\
\hline Infrastructuur & 12 & 16 & 14 & 14 & 19 \\
\hline Totaal & 131 & 139 & 81 & 121 & 113 \\
\hline Overige kosten & 63 & 66 & 32 & 56 & 52 \\
\hline Totaal & 307 & 301 & 176 & 273 & 268 \\
\hline
\end{tabular}




\section{B2.2 Kosten naar kostenplaatsen}

Tabel B2.9 Kosten (euro per ha bos) alle bedrijven naar kostenplaats en omvang bosareaal in ha, 2019

\begin{tabular}{|c|c|c|c|c|c|c|c|}
\hline Kosten & $5-25$ & $25-50$ & $50-100$ & $100-250$ & $\geq 250$ & $\begin{array}{r}\text { Totaal } \\
2019\end{array}$ & $\begin{array}{r}\text { Totaal } \\
2018\end{array}$ \\
\hline \multicolumn{8}{|l|}{ Algemeen bosbeheer } \\
\hline beheer en leiding (arbeid) & 69 & 103 & 75 & 74 & 59 & 71 & 62 \\
\hline Eigenaarslasten & 9 & 12 & 8 & 10 & 6 & 8 & 8 \\
\hline \multicolumn{8}{|l|}{ Bosverjonging } \\
\hline terreinvoorbereiding & 0 & 1 & 0 & 5 & 2 & 2 & 1 \\
\hline Planten & 21 & 16 & 10 & 10 & 9 & 12 & 7 \\
\hline overig bosverjonging & 6 & 35 & 27 & 7 & 7 & 14 & 5 \\
\hline overig bosonderhoud & 180 & 55 & 64 & 71 & 51 & 80 & 80 \\
\hline Totaal & 225 & 79 & 79 & 78 & 62 & 99 & 104 \\
\hline \multicolumn{8}{|l|}{ Houtoogst } \\
\hline blessen en meten & 1 & 2 & 11 & 16 & 4 & 6 & 5 \\
\hline oogst (dunning/eindkap) & 13 & 17 & 38 & 4 & 6 & 13 & 14 \\
\hline overig houtoogst & 12 & 15 & 20 & 5 & 14 & 13 & 22 \\
\hline Totaal & 26 & 35 & 70 & 25 & 24 & 33 & 41 \\
\hline \multicolumn{8}{|l|}{ Infrastructuur } \\
\hline Wegen & 10 & 2 & 5 & 19 & 8 & 9 & 9 \\
\hline
\end{tabular}


Tabel B2.10 Kosten (euro per ha bos) alle bedrijven naar kostenplaats en regio, 2019

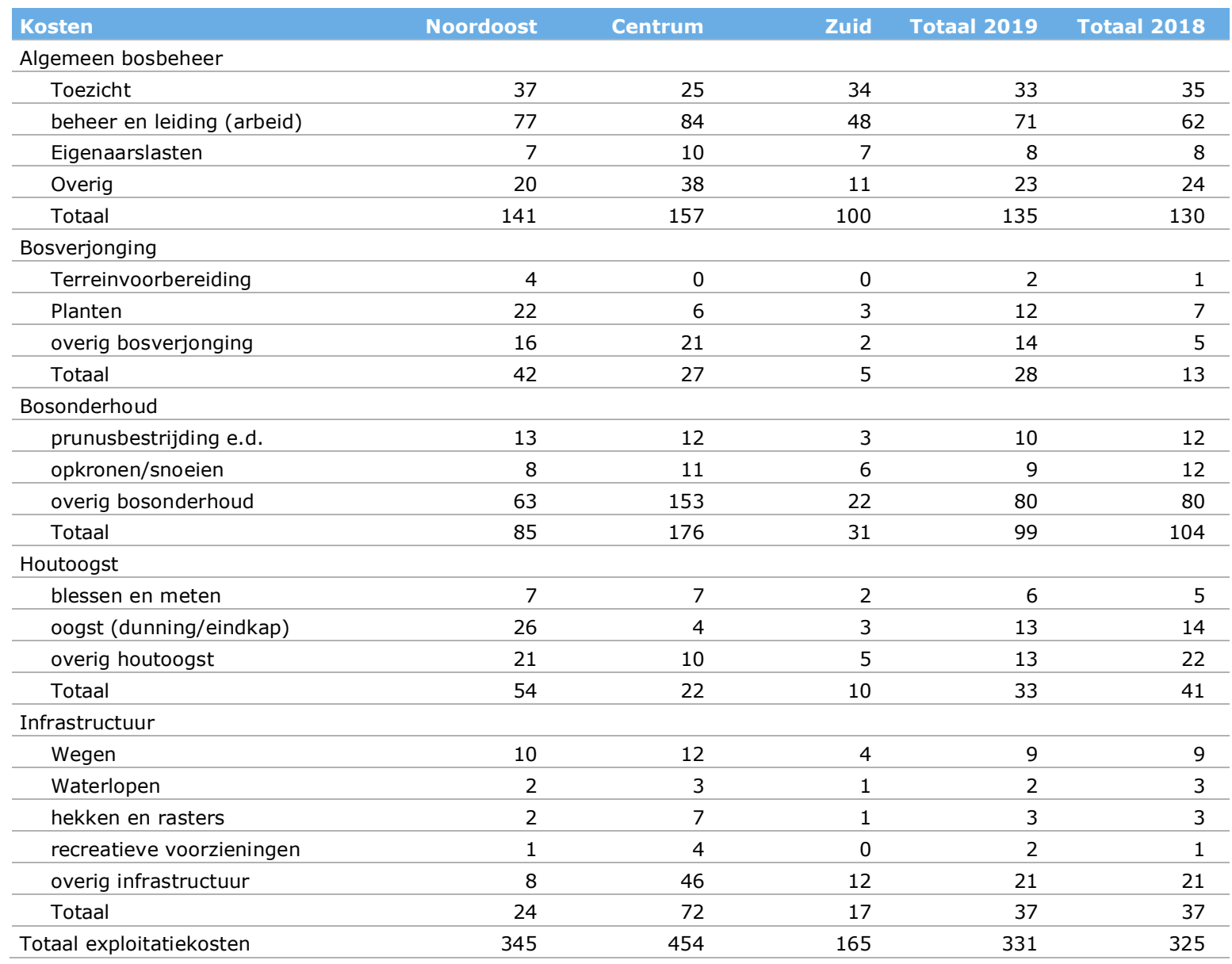


Tabel B2.11 Kosten (euro per ha bos) particuliere bosbedrijven groter dan 50 ha naar kostenplaats en regio, 2019

\begin{tabular}{|c|c|c|c|c|c|}
\hline Kosten & Noordoost & Centrum & Zuid & Totaal 2019 & Totaal 2018 \\
\hline \multicolumn{6}{|l|}{ Algemeen bosbeheer } \\
\hline Toezicht & 32 & 22 & 26 & 27 & 25 \\
\hline Eigenaarslasten & 8 & 7 & 7 & 7 & 7 \\
\hline Overig & 20 & 20 & 10 & 17 & 18 \\
\hline Terreinvoorbereiding & 6 & 0 & 0 & 3 & 2 \\
\hline Planten & 14 & 7 & 3 & 9 & 9 \\
\hline overig bosverjonging & 7 & 24 & 3 & 11 & 6 \\
\hline Totaal & 26 & 31 & 6 & 23 & 16 \\
\hline overig bosonderhoud & 54 & 89 & 26 & 59 & 62 \\
\hline Totaal & 65 & 100 & 36 & 69 & 77 \\
\hline \multicolumn{6}{|l|}{ Houtoogst } \\
\hline blessen en meten & 9 & 10 & 4 & 8 & 5 \\
\hline oogst (dunning/eindkap) & 27 & 0 & 4 & 12 & 13 \\
\hline overig houtoogst & 19 & 10 & 7 & 13 & 19 \\
\hline Totaal & 56 & 20 & 15 & 34 & 37 \\
\hline \multicolumn{6}{|l|}{ Infrastructuur } \\
\hline Wegen & 15 & 10 & 3 & 10 & 10 \\
\hline Waterlopen & 2 & 2 & 1 & 2 & 4 \\
\hline
\end{tabular}




\section{B2.3 Houtoogst en opbrengstprijzen}

Tabel B2.12 Houtoogst ( $m^{3}$ per ha bos) naar omvang bos in ha, 1989-2019

\begin{tabular}{|c|c|c|c|c|c|c|}
\hline & $5-25$ & 25-50 & $50-100$ & $100-250$ & $\geq 250$ & Totaal \\
\hline 1989 & 3,6 & 3,2 & 3,6 & 2,5 & 3,5 & 3,3 \\
\hline 1990 & 3,8 & 4,0 & 3,8 & 3,0 & 4,6 & 4,0 \\
\hline 1991 & 2,3 & 3,6 & 2,8 & 2,2 & 3,4 & 2,9 \\
\hline 1992 & 5,3 & 3,6 & 3,9 & 2,1 & 3,2 & 3,5 \\
\hline 1993 & 2,9 & 2,0 & 2,1 & 3,9 & 3,8 & 3,2 \\
\hline 1994 & 1,3 & 2,3 & 1,9 & 4,2 & 2,9 & 2,9 \\
\hline 1995 & 4,9 & 8,4 & 4,2 & 3,6 & 4,9 & 5,0 \\
\hline 1996 & 2,2 & 3,4 & 2,4 & 2,4 & 3,5 & 2,9 \\
\hline 1997 & 1,3 & 1,8 & 4,7 & 3,0 & 3,3 & 2,8 \\
\hline 1998 & 1,9 & 2,1 & 2,4 & 3,1 & 2,8 & 2,5 \\
\hline 1999 & 0,3 & 1,3 & 4,2 & 2,2 & 5,0 & 2,8 \\
\hline 2000 & 2,6 & 1,4 & 3,0 & 2,6 & 3,1 & 2,6 \\
\hline 2001 & 0,8 & 1,8 & 2,1 & 5,8 & 2,8 & 2,7 \\
\hline 2002 & 0,9 & 1,4 & 2,9 & 2,9 & 3,0 & 2,4 \\
\hline 2003 & 3,6 & 1,8 & 3,5 & 3,6 & 2,6 & 3,0 \\
\hline 2004 & 3,0 & 2,9 & 4,3 & 3,0 & 2,7 & 3,0 \\
\hline 2005 & 5,2 & 3,6 & 3,7 & 2,6 & 2,8 & 3,5 \\
\hline 2006 & 4,1 & 5,5 & 3,6 & 2,7 & 3,6 & 3,8 \\
\hline 2007 & 4,3 & 1,2 & 4,3 & 2,9 & 4,2 & 3,6 \\
\hline 2008 & 2,7 & 2,3 & 4,4 & 2,6 & 2,8 & 2,9 \\
\hline 2009 & 3,1 & 2,3 & 3,8 & 1,4 & 2,6 & 2,6 \\
\hline 2010 & 1,7 & 7,7 & 4,1 & 3,5 & 3,1 & 3,7 \\
\hline 2011 & 2,3 & 4,1 & 3,8 & 5,9 & 3,0 & 3,6 \\
\hline 2012 & 0,8 & 3,5 & 2,5 & 2,4 & 3,2 & 2,5 \\
\hline 2013 & 4,3 & 2,7 & 5,7 & 3,2 & 3,5 & 3,8 \\
\hline 2014 & 4,1 & 3,5 & 2,5 & 3,1 & 4,1 & 3,6 \\
\hline 2015 & 4,2 & 2,9 & 3,8 & 2,5 & 3,2 & 3,3 \\
\hline 2016 & 3,0 & 1,2 & 1,7 & 4,2 & 3,0 & 2,8 \\
\hline 2017 & 2,6 & 1,4 & 2,4 & 4,0 & 2,9 & 2,7 \\
\hline 2018 & 1,1 & 2,5 & 2,8 & 3,4 & 3,4 & 2,8 \\
\hline 2019 & 1,4 & 1,3 & 4,1 & 3,0 & 3,2 & 2,7 \\
\hline \multicolumn{7}{|l|}{ Waarvan in 2019} \\
\hline op stam & 0,8 & 1,3 & 2,8 & 3,0 & 3,2 & 2,4 \\
\hline Geveld & 0,5 & 0,0 & 1,3 & 0,0 & 0,0 & 0,3 \\
\hline \multicolumn{7}{|l|}{ Waarvan in 2019} \\
\hline eiken & - & - & - & - & - & 0,13 \\
\hline Beuken & - & - & - & - & - & 0,03 \\
\hline populier en wilg & - & - & - & - & - & 0,03 \\
\hline ongespecif. Loofhout & - & - & - & - & - & 0,03 \\
\hline loof-/naaldhout & - & - & - & - & - & 0,29 \\
\hline Dennen & - & - & - & - & - & 0,28 \\
\hline Douglas & - & - & - & - & - & 0,12 \\
\hline (fijn)spar & - & - & - & - & - & 0,31 \\
\hline Larix & - & - & - & - & - & 0,12 \\
\hline ongespecif. naaldh. & - & - & - & - & - & 0,19 \\
\hline
\end{tabular}


Tabel B2.13 Opbrengstprijzen (euro per $\mathrm{m}^{3}$ ) op stam en geveld verkocht hout naar regio, 1996-2019

\begin{tabular}{|c|c|c|c|c|}
\hline $\begin{array}{l}\text { Verkoopwijze, } \\
\text { Oogstmethode }\end{array}$ & Noordoost & Centrum & Zuid & Totaal \\
\hline \multicolumn{5}{|c|}{ Op stam verkocht, dunning } \\
\hline 1997 & 10,5 & 14,6 & 10,8 & 12,2 \\
\hline 1998 & 14,6 & 15,6 & 10,4 & 13,8 \\
\hline 2001 & 7,7 & 15,4 & 12,1 & 11,9 \\
\hline 2002 & 15,0 & 17,2 & 10,6 & 14,6 \\
\hline 2003 & 14,4 & 14,7 & 9,9 & 12,6 \\
\hline 2004 & 14,8 & 12.2 & 12,3 & 13,3 \\
\hline 2008 & 22,4 & 27,5 & 24,7 & 24,0 \\
\hline 2009 & 26,5 & 24,4 & 16,8 & 23,4 \\
\hline \multicolumn{5}{|c|}{ Op stam verkocht, eindkap } \\
\hline 1996 & 16,1 & 18,2 & 14,9 & 15,8 \\
\hline 1997 & 15,1 & 12,3 & 14,4 & 14,0 \\
\hline 1998 & 17,8 & 17,6 & 9,3 & 15,9 \\
\hline 1999 & 6,8 & 15,3 & 17,8 & 10,3 \\
\hline 2000 & 17,0 & 13,6 & 24,0 & 18,2 \\
\hline 2001 & 17,1 & 19,3 & 20,0 & 18,0 \\
\hline 2002 & 14,4 & 19,0 & 16,7 & 16,0 \\
\hline 2009 & - & 40,8 & 10,0 & 30,8 \\
\hline \multicolumn{5}{|c|}{ Op stam verkocht (dunning en eindkap) } \\
\hline 2010 & 30,8 & 39,2 & 19,0 & 27,9 \\
\hline 2011 & 33,7 & 38,3 & 27,2 & 34,3 \\
\hline 2012 & 34,6 & 49,3 & 28,1 & 37,6 \\
\hline 2013 & 39,4 & 36,8 & 33,1 & 37,6 \\
\hline 2014 & 43,4 & 37,9 & 25,1 & 38,0 \\
\hline 2015 & 37,8 & 47,0 & 31,7 & 38,2 \\
\hline 2016 & 39,7 & 42,2 & 32,7 & 39,6 \\
\hline 2017 & 39,3 & 41,5 & 23,3 & 36,2 \\
\hline 2018 & 40,2 & 42,7 & 36,4 & 40,9 \\
\hline 2019 & 31,6 & 33,6 & 27,3 & 31,8 \\
\hline
\end{tabular}


Tabel B2.13 (vervolg) Opbrengstprijzen (euro per $\mathrm{m}^{3}$ ) op stam en geveld verkocht hout naar regio, 1996-2019

\begin{tabular}{|c|c|c|c|c|}
\hline $\begin{array}{l}\text { Verkoopwijze, } \\
\text { Oogstmethode }\end{array}$ & Noordoost & Centrum & Zuid & Totaal \\
\hline \multicolumn{5}{|c|}{ Geveld verkocht, dunning } \\
\hline 1997 & 29,5 & 28,6 & 27,3 & 28,6 \\
\hline 1998 & 26,5 & 19,0 & 22,8 & 24,0 \\
\hline 2001 & 30,9 & 28,4 & 22,9 & 29,4 \\
\hline 2002 & 28,0 & 33,6 & 22,4 & 28,5 \\
\hline 2003 & 32,3 & 36,4 & 15,0 & 31,0 \\
\hline 2004 & 21,5 & 33,4 & 18,5 & 23,3 \\
\hline 2008 & 41,5 & 42,5 & 50,4 & 41,9 \\
\hline 2009 & 33,1 & 69,6 & 44,5 & 43,5 \\
\hline \multicolumn{5}{|c|}{ Geveld verkocht, eindkap } \\
\hline 1996 & 25,0 & 16,4 & - & 23,1 \\
\hline 1997 & 28,5 & - & - & 28,5 \\
\hline 1998 & 17,8 & 43,5 & - & 21,0 \\
\hline 1999 & 34,1 & 29,9 & 40,8 & 34,2 \\
\hline 2000 & - & 24,1 & - & 24,1 \\
\hline 2001 & 41,3 & 24,4 & - & 33,1 \\
\hline 2002 & 30,7 & 41,6 & - & 39,3 \\
\hline 2009 & 29,3 & - & - & 29,3 \\
\hline \multicolumn{5}{|c|}{ Geveld verkocht (dunning en eindkap) } \\
\hline 2010 & 43,0 & 52,4 & 33,9 & 45,6 \\
\hline 2011 & 50,1 & 57,3 & - & 51,0 \\
\hline 2012 & 50,8 & 61,1 & - & 54,2 \\
\hline 2013 & 45,4 & 34,7 & - & 40,4 \\
\hline 2014 & 59,5 & 79,5 & - & 61,8 \\
\hline 2015 & 52,0 & - & - & 54,8 \\
\hline 2016 & 64,3 & 56,5 & - & 62,5 \\
\hline 2017 & 51,6 & - & - & 59,5 \\
\hline 2018 & 55,0 & - & - & 52,5 \\
\hline 2019 & 62,3 & - & - & 59,1 \\
\hline
\end{tabular}


Tabel B2.14 Opbrengstprijzen (euro per $\mathrm{m}^{3}$ ) op stam en geveld verkocht hout naar omvang bosareaal in ha, 1996-2019

\begin{tabular}{|c|c|c|c|c|c|c|}
\hline $\begin{array}{l}\text { Verkoopwijze, } \\
\text { Oogstmethode }\end{array}$ & $5-25$ & $25-50$ & $50-100$ & $100-250$ & $\geq 250$ & Totaal \\
\hline \multicolumn{7}{|c|}{ Op stam verkocht, dunning } \\
\hline 1997 & 5,7 & 12,3 & 11,9 & 13,9 & 13,8 & 12,2 \\
\hline 1998 & 8,0 & 16,9 & 16,1 & 10,8 & 13,9 & 13,8 \\
\hline 2001 & - & 18,6 & 17,2 & 6,0 & 15,2 & 11,9 \\
\hline 2002 & 28,4 & 13,5 & 15,3 & 13,7 & 14,7 & 14,6 \\
\hline 2003 & 8,6 & 22,0 & 11,9 & 11,6 & 13,3 & 12,6 \\
\hline 2004 & 12,1 & 23,8 & 9,2 & 11,7 & 15,6 & 13,3 \\
\hline 2008 & 16,9 & 17,8 & 26,2 & 26,6 & 26,4 & 24,0 \\
\hline 2009 & 15,1 & 24,1 & 26,0 & 18,3 & 27,1 & 23,4 \\
\hline \multicolumn{7}{|c|}{ Op stam verkocht, eindkap } \\
\hline 1996 & - & 15,6 & 17,1 & 13,3 & 16,2 & 15,8 \\
\hline 1997 & - & 17,6 & 15,1 & 12,2 & 13,9 & 14,0 \\
\hline 1998 & - & 19,9 & 13,3 & 16,8 & 14,6 & 15,9 \\
\hline 1999 & - & 22,0 & 13,6 & 20,2 & 6,9 & 10,3 \\
\hline 2000 & - & - & 15,3 & 28,0 & 18,9 & 18,2 \\
\hline 2001 & - & 18,2 & 16,4 & 17,4 & 19,4 & 18,0 \\
\hline 2002 & - & - & 11,9 & 11,7 & 18,3 & 16,0 \\
\hline 2009 & 10,0 & - & - & - & 40,8 & 30,8 \\
\hline \multicolumn{7}{|c|}{ Op stam verkocht (dunning en eindkap) } \\
\hline 2010 & 23,7 & 19,6 & 34,0 & 29,5 & 33,3 & 27,9 \\
\hline 2011 & 27,8 & 38,4 & 24,9 & 34,7 & 38,3 & 34,3 \\
\hline 2012 & 46,0 & 39,5 & 37,8 & 32,5 & 37,9 & 37,6 \\
\hline 2013 & 31,8 & 30,0 & 49,6 & 33,5 & 38,1 & 37,6 \\
\hline 2014 & 51,2 & 28,5 & 40,7 & 35,2 & 34,3 & 38,0 \\
\hline 2015 & 39,9 & 38,8 & 34,9 & 41,9 & 37,8 & 38,2 \\
\hline 2016 & 18,8 & 24,6 & 45,3 & 38,9 & 42,1 & 39,6 \\
\hline 2017 & 24,2 & 47,8 & 55,2 & 43,3 & 30,1 & 36,2 \\
\hline 2018 & - & 43,6 & 45,1 & 34,8 & 43,7 & 40,9 \\
\hline 2019 & 23,7 & 28,0 & 34,5 & 28,0 & 33,4 & 31,8 \\
\hline
\end{tabular}


Tabel B2.14 (vervolg) Opbrengstprijzen (euro per $\mathrm{m}^{3}$ ) op stam en geveld verkocht hout naar omvang bosareaal in ha, 1996-2019

\begin{tabular}{|c|c|c|c|c|c|c|}
\hline $\begin{array}{l}\text { Verkoopwijze, } \\
\text { Oogstmethode }\end{array}$ & $5-25$ & $25-50$ & $50-100$ & $100-250$ & $\geq 250$ & Totaal \\
\hline \multicolumn{7}{|c|}{ Geveld verkocht, dunning } \\
\hline 1997 & 27,6 & 27,0 & 25,6 & 27,9 & 30,8 & 28,6 \\
\hline 1998 & 14,5 & 20,9 & 25,1 & 33,1 & 42,9 & 24,0 \\
\hline 2001 & 24,1 & 28,5 & 18,0 & 31,6 & 36,6 & 29,4 \\
\hline 2002 & 26,4 & 12,3 & 22,0 & 23,2 & 36,3 & 28,5 \\
\hline 2003 & 25,9 & 19,6 & 33,0 & 20,3 & 39,5 & 31,0 \\
\hline 2004 & 14,1 & 28,1 & 27,1 & 31,4 & 32,3 & 23,3 \\
\hline 2008 & 33,6 & 39,9 & 35,8 & 38,8 & 50,2 & 41,9 \\
\hline 2009 & 64,0 & 43,9 & 28,2 & 50,7 & 30,2 & 43,5 \\
\hline \multicolumn{7}{|c|}{ Geveld verkocht, eindkap } \\
\hline 1996 & - & 6,8 & - & 25,0 & 21,1 & 23,1 \\
\hline 1997 & - & - & 26,5 & 35,3 & 27,3 & 28,5 \\
\hline 1998 & 13,3 & - & 23,7 & 29,2 & 42,8 & 21,0 \\
\hline 1999 & - & 43,2 & - & 28,5 & 25,6 & 34,2 \\
\hline 2000 & - & - & - & - & 24,1 & 24,1 \\
\hline 2001 & - & 41,3 & - & - & 24,4 & 33,1 \\
\hline 2002 & - & - & - & - & - & 39,3 \\
\hline 2009 & 30,0 & - & - & 28,0 & - & 29,3 \\
\hline \multicolumn{7}{|c|}{ Geveld verkocht (dunning en eindkap) } \\
\hline 2010 & 56,4 & 67,8 & 50,0 & 34,8 & 41,0 & 45,6 \\
\hline 2011 & 56,5 & 47,8 & - & 48,2 & 34,1 & 51,0 \\
\hline 2012 & 54,1 & - & - & - & 55,1 & 54,2 \\
\hline 2013 & 53,9 & 32,3 & - & - & 41,8 & 40,4 \\
\hline 2014 & 65,6 & 46,0 & - & - & 66,7 & 61,8 \\
\hline 2015 & 60,5 & 42,8 & - & - & 51,8 & 54,8 \\
\hline 2016 & 61,5 & - & - & 53,1 & 68,7 & 62,5 \\
\hline 2017 & 83,6 & 39,6 & 57,7 & 51,0 & 64,5 & 59,5 \\
\hline 2018 & 57,1 & - & - & - & - & 52,5 \\
\hline 2019 & 58,1 & - & - & - & - & 59,1 \\
\hline
\end{tabular}


Tabel B2.15 Opbrengstprijzen (euro per $\mathrm{m}^{3}$ ) naar houtsoort en verkoopwijze, 2015-2019

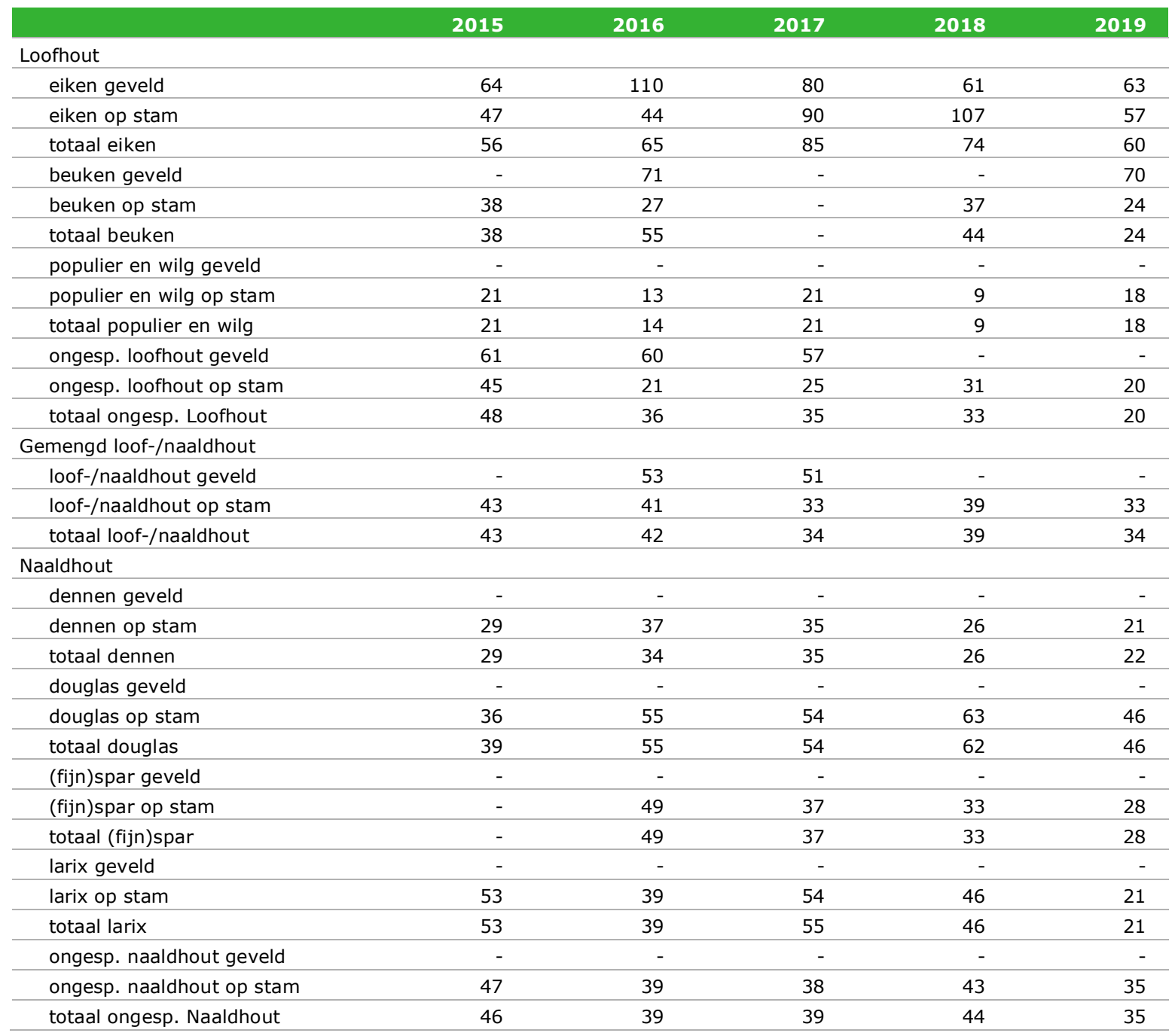


Wageningen Economic Research Postbus 29703

2502 LS Den Haag

T 0703358330

Ecommunications.ssg@wur.nl

www.wur.nl/economic-research

Wageningen Economic Research RAPPORT

2021-044
De missie van Wageningen University \& Research is 'To explore the potential of nature to improve the quality of life'. Binnen Wageningen University \& Research bundelen Wageningen University en gespecialiseerde onderzoeksinstituten van Stichting Wageningen Research hun krachten om bij te dragen aan de oplossing van belangrijke vragen in het domein van gezonde voeding en leefomgeving. Met ongeveer 30 vestigingen, 6.500 medewerkers ( $5.500 \mathrm{fte}$ ) en 12.500 studenten behoort Wageningen University \& Research wereldwijd tot de aansprekende kennisinstellingen binnen haar domein. De integrale benadering van de vraagstukken en de samenwerking tussen verschillende disciplines vormen het hart van de unieke Wageningen aanpak. 



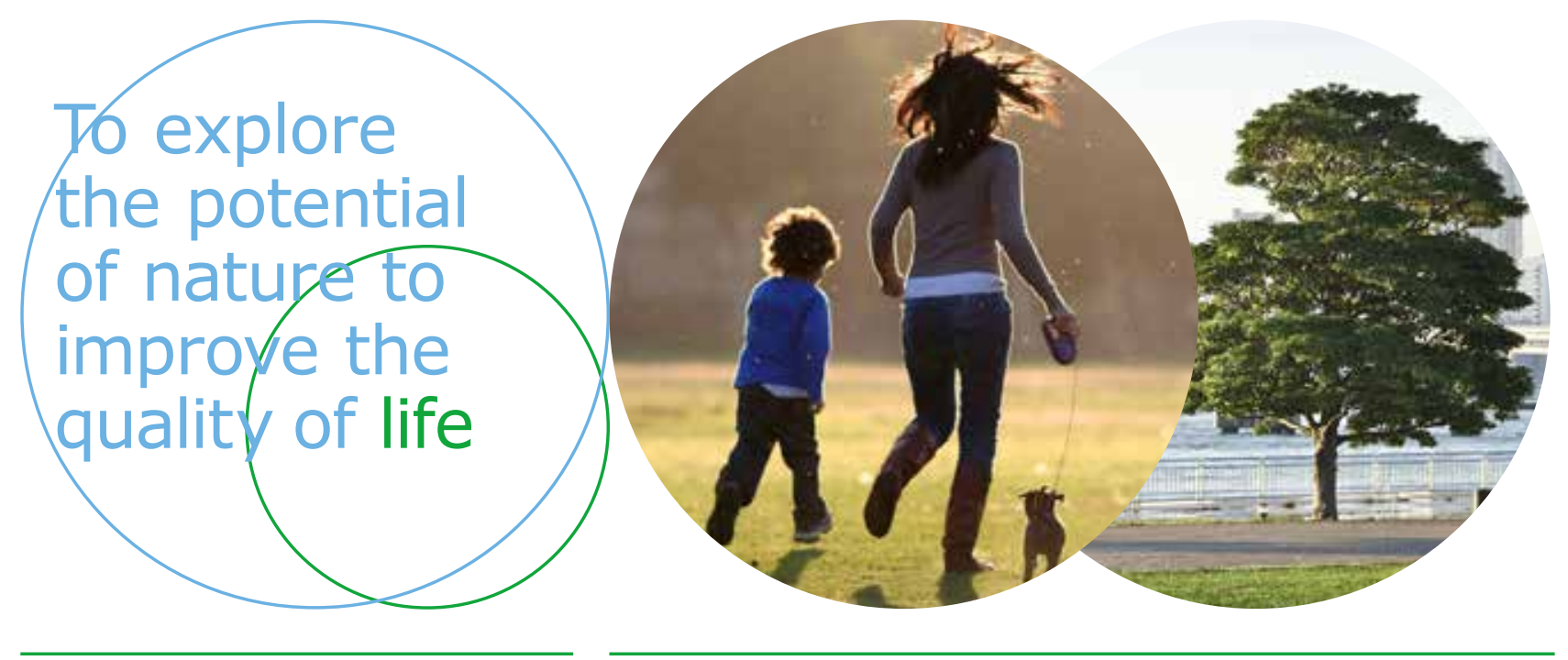

Wageningen Economic Research Postbus 29703

2502 LS Den Haag

T 0703358330

E communications.ssg@wur.nl www.wur.nl/economic-research

Rapport 2021-044

ISBN 978-94-6395-803-5
De missie van Wageningen University \& Research is 'To explore the potential of nature to improve the quality of life'. Binnen Wageningen University \& Research bundelen Wageningen University en gespecialiseerde onderzoeksinstituten van Stichting Wageningen Research hun krachten om bij te dragen aan de oplossing van belangrijke vragen in het domein van gezonde voeding en leefomgeving. Met ongeveer 30 vestigingen, 6.500 medewerkers ( $5.500 \mathrm{fte}$ ) en 12.500 studenten behoort Wageningen University \& Research wereldwijd tot de aansprekende kennisinstellingen binnen haar domein. De integrale benadering van de vraagstukken en de samenwerking tussen verschillende disciplines vormen het hart van de unieke Wageningen aanpak. 